\title{
Esboço de uma Teoria da Música: Para além de uma Antropologia sem Música e de uma Musicologia sem Homem1
}

\author{
Rafael José de Menezes Bastos \\ Universidade Federal de Santa Catarina
}

Preâmbulo

Os nossos esperam os vossos².

Se os musicólogos ignoram o povo, os antropólogos ignoram o som.

(Feld ms.)

O primeiro contexto da presente discussão é o das teorias elaboradas nos últimos cerca de cem anos pela Etnomusicologia sobre:

1. a definição de seu próprio campo; e

2. a da música como categoria objeto de seu conhecimento.

Ele aqui comparecerá, entretanto, apenas como pano de fundo. Minha intenção é concentrar-me nas décadas de 50 e 60 deste século. Aí ocorreram fatos fundamentais na direção da conformação da disciplina, tipicamente nos Estados Unidos:

a. O paulatino abandono da expressão Musicologia Comparada como nome da área de conhecimento;

b. a correspondente afirmação de seu atual nome, Etnomusicologia, inicialmente grafado com hífen (Etno-Musicologia);

c. a criação em 1955 da Society for Ethnomusicology; sucessora da fugaz (na década de 30) American Society for Comparative Musicology;

${ }^{1}$ Publicado originalmente em MENEZES BASTOS, Rafael. "Esboço de uma Teoria da Música: Para Além de uma Antropologia Sem Música e de uma Musicologia Sem Homem.“ in Anuário Antropológico/1993, Rio de Janeiro: Tempo Brasileiro, 1995. pp. 9-73

2 Escrito num ossário do Cemitério da Quinta dos Lázaros, na Bahia. Joselina de Menezes Bastos, minha mãe, constantemente usava este dito como apontamento crítico àquilo tudo que lhe parecia veleidade modernista. 
d. a cristalização da comunidade científica etnomusicógica. Isto se expressa especialmente pela publicação, em 1964 e arredores, de alguns clássicos, entre os quais The Anthropology of Music (Merriam, 1964).

A redução cronológica e nacional em consideração não redundará em prejuízo de uma visão global da área. Pelo contrário, as referidas décadas norteamericanas representam o projeto etnomusicológico como um todo: reafirmam seus germes originais de pensamento, assumem por completo seu dilema e apontam para deslocamentos na disciplina, previsíveis em suas origens.

Incluído neste contexto, o exame localiza-se também no contexto geral atinente às questões I e 2 acima - das diversas outras musicologias, isto é, Musicologia Histórica, Sociologia e Psicologia da Música, Estética e Folclore Musicais. Isto será ensaiado - de maneira modesta, entretanto - através da análise de alguns autores das referidas áreas, sobretudo europeus. Aqui também as décadas de 50 e 60 merecerão enfoque central, opção que fiz por razões semelhantes às expostas para o caso da Etnomusicologia.

Finalmente, a presente discussão também trabalha os nexos da Antropologia com a música e a Etnomusicologia. O célebre dilema etnomusicológico (Merriam, 1969: 213) não é uma construção exclusivamente etnomusicológica. Tal dilema, congênito nesta área de estudos, estabelece a música como constituída por dois planos de abordagem: o dos sons (ou música) e o dos comportamentos (ou cultura). O primeiro mereceria uma análise musicológica, sendo que o segundo exigiria um exame antropológico (conforme as expressões de Merriam, 1969: 2 13). Entre estes dois planos, as relações seriam de determinação do primeiro pelo segundo, o que porém nunca se explicita claramente senão em termos de um vago mecanicismo projetivo do comportamento sobre o som. Tal postura nunca mereceu crítica antropológica, o que lhe concede legitimidade na disciplina, mesmo que por omissão.

Esta legitimidade não se esgota, porém, no plano da omissão crítica. Ela pode também ser rastreada pelo exame de atitudes usuais com relação à música - enquanto objeto de estudo -, vigentes na cultura antropológica, sobretudo em sua tradição oral. Entre estas atitudes, registro a da redução da música especificamente, do som segundo Merriam - ao sistema de notação da Música Ocidental. Tal redução estaria na base da afirmação de que o estudo da música (de suas tecnicalidades) seria inacessível ao antropólogo, constituindo algo de específico, particular, oposto assim ao geral (cultura), que seria o cerne desta Antropologia Sem Música com relação à Musicologia Sem Homem33.

A atitude referida não é típica apenas do conjunto das relações vigentes entre a Antropologia e a Etnomusicologia, reproduzindo-se globalmente nos campos intersticiais das Ciências Humanas com as respectivas musicologias. Por exemplo, entre a Sociologia e a Sociologia da Música; entre a História e a Musicologia Histórica.

3. A forma portuguêsa geral tem sua matriz no verbo latino generare, que tem como sentidos próprios engendrar, gerar, dar o ser (daí, genitor). Seus sentidos figurados são: produzir, criar, compor (daí, general de patente militar). 
Assim contextualizada, a presente discussão intenciona uma reflexão sobre a música, suas disciplinas científicas (aqui chamadas de musicologias) - com ênfase na Etnomusicologia - e suas vizinhas da área das Ciências Humanas, a Antropologia centralmente. Esta reflexão será de escopo antropológico pelo estranhamento que procurará produzir no sentido da construção de todos esses alguns - às vezes, nós - como outros. Em última instância, ambiciono pensar sobre a música no pensamento Ocidental, toma- das as musicologias - a ciência, pois - como instante privilegiado deste. Tal o exercício que farei, na direção tanto da maior navegabilidade no mundo da música Kamayurá quanto do desnudamento do dilema etnomusicológico. Esse dilema, com todas as suas ambigüidades - o terreno por excelência, assim, para a manipulação -, é apenas a realização regional etnomusicológica daquilo que denomino de paradoxo musicológico. Um paradoxo é a inversão de uma ideologia, operando com relação a esta a mudança de sinal4.

Os nativos ocidentais, como quaisquer outros nativos, são capazes de operacionalizar, com alto grau de consistência, a interface da música com os outros sistemas da vida sócio-cultural. Quer dizer, o seu contexto, expresso pelo universo de seus usos. Desta maneira, colam, por exemplo, a Marcha Fúnebre às vestes negras, aos corpos constritos, às lágrimas, flores, tudo reunindo na direção da composição do evento enterro. O conjunto destas operações é dominado pela verbalização de normas conscientes (por exemplo: "no enterro, as músicas devem ser tristes"). Estas normas são ad hoc com relação a cada evento ou domínio, constituindo uma ideologia ou senso comum em toda e qualquer sociedade.

No campo científico, porém - no das musicologias -, essa fluência é problemática, esterilizando-se nas dificuldades de evidenciação das regras de conjunção (contextualização) da música com os outros sistemas e vice- versa. Estas regras, do terreno das representações coletivas, são inconscientes. Ademais, sendo de contextualização - de encadeamento sintagmático, pois -, necessariamente atuam também no plano dos paradigmas componentes e atravessam domínios. Eis aí a essência do dilema etnomusicológico: como reduzir a expressão da música (o som) - sua fonologia e gramática - a seu contexto (o comportamento) e vice -versa? Afinal, a Marcha Fúnebre também pode ocorrer numa laica aula de História da Música ou num brilhante dia de verão na casa de um amante nada funéreo de Chopin. A que a Marcha Fúnebre, então, que pode estar junto com textos tão diversos?

A busca da solução deste dilema tem sido realizada nestes cerca de cem anos de Etnomusicologia basicamente no mesmo eixo em que ele viceja: no da interface contextuaI. Parte-se aqui da crença na determinação da expressão pelo contexto musical e, correspondentemente, da descrença na pertinência mesma de um plano de conteúdo desta linguagem. Tem-se procurado, assim, no âmbito de uma Pragmática Musical e, desta maneira, em termos contextuais da música,

4 A palavra paradoxo tem origem grega: o sufixo pará (que dá a idéia de contraste) mais o nome dáxos (aparência, senso comum). Um paradoxo, pois, inverte uma ideologia, no sentido de falsa conciéncia (Mannheim 1950) ou do portugues mentira (do latim, mentiri), algo que de tão mental é falso, não sabendo pois a real, embora o imite e finja. 
a resolução das questões de ordem fonológico-gramaticai desta linguagem e de sua interface contextual, esta admitida como estruturante do som. Isto caracteriza, em essência, não somente a abordagem etnomusicológica mas, em bloco, o conjunto das musicologias conforme procurarei mostrar na segunda parte deste texto.

O que se pode assim verificar como tendência central da Etnomusicologia é que a busca de equacionamento da problemática da interface contextual da música tem sido feita, em todos esses anos, em termos eles mesmos contextuais. Paralelamente a isto, tem-se cedido lugar, na grande maioria das vezes, à negação de semanticidade à música, que assim é decretada como se nada "enviando". Isto está agudamenta consignado na epígrafe a este texto. O que faz ela? Congela a linguagem musical (minimizada ao som) na sensorialidade pura, desapropriando-a de toda inteligibilidade. Isto constitui um absurdo, lugar de nascimento das tautologias que dominam as elaborações sobre a questão do sentido musical feitas de dentro das Ciências Humanas e de suas satelizadas musicologias. Por outro lado, na república ático-espartana de Platão (segundo Adorno, conforme adiante), isto aponta relações de poder entre entendedores e sentidores, vitória de Pirro dos primeiros sobre os outros.

Superar o paradoxo musicológico significa superar suas duas dobras: a de sinal positivo, constituída pelo senso comum das normas conscientes e ad hoc de contextualização; tanto quanto a de sinal negativo, de paralisia quanto a descoberta das correspondentes regras inconscientes.

Somente o projeto de uma Semântica Musical pode levar isto a termo. Este projeto, recortando o que é sentido o que é contexto, parte da pertinência e validade de um plano de conteúdo musical, codificado no de expressão. Assim procedendo, recompõe a integralidade da música como linguagem, o que sua condenação ao contexto - tão bem traduzida pela minimização sonora - lhe extirpou.

Uma das características fundamentais da linguagem, sem a qual ela não existe, e exatamente a da escolha com relação ao contexto. No projeto, pois, de uma Semântica Musical, está o aceno que estes fins de século e milênio fazem na direção do equacionamento científico adequado da música. Como o de qualquer Semântica, porém, este não é um intento fácil, daí a dissecação que farei de sua problemática, que por não ser ingênua parte daquela que considero uma das aprendizagens mais fundamentais da História da Antropologia: "A música é social não só por seu conteúdo, mas também em sua forma "5. Este pensamento, na base do estudo que fiz da música dos índios Kamayurá, é fundamental na direção do estranhamento do paradoxo musicológico e, assim, do restabelecimento da linguagem musical enquanto sistema significante e de significado.

5 Conforme Mauss (1979: 118), onde substituí prece por música, num exercício que considero feliz não só devido ao falo de ambos os discursos (música e prece) serem voco-sonoros. 
Merriam (1977: 189-190), num importante estudo sobre a história da delimitação do campo da Etnomusicologia, chama a atenção para o fato de que uma delimitação destas pode cobrir tanto o que a disciplina deve abarcar no entendimento de cada autor quanto o que ela efetivamente abrange.

É importante que se levante desde o início a existência deste descompasso entre intenção e efetivação do projeto disciplinar etnomusicológico, descompasso este típico da diplomacia de toda e qualquer ciência.

Adler (1885: 14), o primeiro a cunhar uma definição de Etnomusicologia"6, assim a vê:

\begin{abstract}
Uma nova e extremamente importante sub-região desta parte sistemática é a "Musikologie", isto é, a Musicologia Comparada, cuja tarefa é comparar a produção tonal, especialmente os cânticos folclóricos dos diferentes povos, países e territórios, com propósito etnográfico e classificá-la, na sua diversidade, de acordo com suas características.
\end{abstract}

A categoria Tonproducte, que traduzi por produção tonal, é o núcleo da definição em análise. Seu uso - e, não, simplesmente o da palavra Musik (música) - evidencia uma diligência e profundidade de intenções invejáveis em quem escreveu, há cerca de cem anos, em torno do binômio relativismouniversalismo.

A preferência de Adler pelo substantivo Ton coloca todo o contínuo de discursos voco-sonoros como objeto de estudo da Musicologia Comparada. Isto, além de logo estranhar a categoria Ocidental música. Note-se que estou a tratar a palavra Ton como uma categoria nativa, daí a necessidade de uma sua hermenêutica - como das demais sublinhadas na citação -, não fique sua compreensão entregue à obviedade.

Ao usar essa categoria, Adler estabelece a Musicologia Comparada face a um objeto muito mais amplo, no plano intencional, do que aquele que efetivamente construiu. Isto se concretiza mais ainda pela ancoragem que sofre esse Ton: trata-se de uma pro-dução, isto é, algo que está a meio caminho entre (pro-) o produtor e o consumidor, não se esgotando em si mesmo embora tenha concretude.

Indo adiante na reflexão, Adler apresenta a finalidade da primeira tarefa da Musikologie: "comparar a produção tonal [...] com propósito etnográfico".

O conceito de Etnografia, que se firma na primeira metade do século XIX a partir de uma prática que remonta ao XVIII (Copans, 1974: 23; Harris, 1979: 14-16) -, tem aí a acepção de "classificação dos grupos humanos a partir de suas características linguísticas" (Copans, 1974: 23). Observe-se desde já a primordialidade do aspecto linguístico nesta Etnografia.

De formação anterior a este, o conceito de Etnologia é o de "um ramo da Filosofia da História e depois a análise das características raciais", de acordo ainda com Copans. Este mesmo autor (1974: 23) aponta que os dois campos só se reunirão no quadro de uma única disciplina em fins do século passado,

${ }^{6}$ A não ser que dito em contrário, todas as traduções aqui apresentadas (com seus diacríticos de ênfase) são de minha autoria. Boilês \& Natriez (1977) e Merriam (I977) foram usados na reconstituição da história da delimitação do objeto da Etnomusicologia. Sobre a Musicologia Comparada, utilizei Pinto (I983) e Graf (I974). 
exatamente a época do texto de Adler em exame. A partir daí, Etnografia implica em coleta e descrição, ficando a Etnologia com a comparação.

A conceituação adleriana de Etnografia, porém - segundo o texto em comentário indiretamente pode evidenciar -, é muito mais a da Etnologia de acordo com a indicação de Copans. Nas palavras de Adler, o que seria a Etnografia de Copans estaria sem rótulo, coberto pela expressão: "classificá-la, na sua diversidade, de acordo com suas características" (eu leria: características concreto-materiais).

Sugiro que nesta operação de classificação está a segunda tarefa da Musicologia Comparada de Adler. Esta tarefa se explicitaria pelo estudo da concretude material-sonora da produção tonal. No sentido desta interpretação, note-se a nítida complementariedade que existe no texto entre as operações comparar e classificar, complementariedade que se expressa no par etnográfico (isto é, linguístico-cultural)/tonal (quer dizer, voco-sonoro). Admito que é este tonal o rótulo oculto na expressão classificá-la, que é, desta maneira, atinente ao mundo voco-sonoro.

Sumarizando em termos de categorias hoje correntes, a definição adleriana de Musicologia Comparada seria bifácie: de um lado, ela seria uma Antropologia; de outro, uma Musicologia. Seu objeto: os discursos voco-sonoros humanos.

A que vem, entretanto, nessa definição tão ampla de Musicologia Comparada, a especificação dos "cantos folclóricos dos diferentes povos, países e territórios"?

O substantivo grego éthnos ("povo") está para a Europa, a partir do Renascimento, como o termo bárbaros esteve para o mundo grego antigo. Os éthne ("povos") não são aí, desta maneira, simplesmente "povos" mas em bloco e residualmente os "outros", aqueles povos pagãos, não-cristãos7.

De repente, no texto de Adler, o salto da intenção à efetivação: de produção tonal a cântico; daí, a cântico folclórico. Tal compressão, entretanto, não para no plano temático: ela se explicita também espacialmente, até territórios, isto é, domínios, colônias - terras onde habitam éthne ou, em alemão, Võlker (plural).

Aí, neste salto, a verificação de que a Musicologia Comparada não é uma logia desencarnada, mas uma Etno-(musico)-logia na direção da construção do binómio "nós"/"outros". Aí, a sua amarração histórico-cultural, no sentido do entendimento da qual o estudo das relações entre a Antropologia e a Música com o colonialismo e com a construção dos estados- nações modernos é de importância fundamental. Trato disto, de maneira breve, na tercei ra parte do presente escrito.

Cerca de setenta anos depois dessa conceituação inaugural de Musicologia Comparada, Kunst (1950: 7) definirá a Etno-Musicologia (com hífen) da seguinte maneira: ela estuda

7 Corominas (1954, vol. II: 459) informa que o uso deste termo (plural, éthnei, documentado em espanhol pela primeira vez em 1630, foi feita pelos tradutores judeus da Bíblia, que o aplicaram aos povos estrangeiro, politeístas. 
a música e os instrumentos musicais de todos os povos não-europeus, incluindo tanto os chamados povos primitivos quanto as nações civilizadas orientais. Muito embora esta ciência naturalmente faça incursões repetidas no campo da música européia, esta é, em si mesma, só um objeto indireto de seu estudo.

De Adler (1885) a Kunst (1950), a transformação daquilo que quase estava entre parênteses em centro definicional da disciplina. Isto mostra como delimitações de campos científicos nunca são monolíticas, contendo os elementos que apontam para a natureza dinâmica do campo-objeto.

Na definição adleriana, os cânticos folclóricos - na redução mínima, a música vocal dos povos dos territórios, isto é, basicamente os primitivos - são elementos marginais, intrometidos na conceituação do autor. Já em Kunst, eles, convertidos na música e nos instrumentos musicais dos povos não-europeus, são escancaradamente o núcleo de atenção da Etno-Musicologia, com hífen segundo a escrita até 1955 (vide adiante).

Por outro lado, a música européia, que em Adler está implícita como possibilidade de produção tonal e que, assim, estaria no centro das atenções da Musicologia Comparada (como qualquer produção tonal, entretanto), para Kunst é objeto tão somente indireto da Etno-Musicologia.

Tudo isto, porém, somente no plano das intenções. No das efetivações, oco rre outra inversão: na Musicologia Comparada feita da definição de Adler em diante (conforme, a seguir, o estudo da Escola de Berlim), a música primitiva será tema praticamente exclusivo e a música européia, irrelevante. Já na Etnomusicologia - libertada afinal do hífen - que se elaborará a partir da conceituação de Kunst (de acordo com o exame que farei das décadas norteamericanas de 50 e 60), a música européia, embora nunca como tema nuclear, será um objeto cada vez mais presente.

O que se passou nesses setenta anos foi a sedimentação de um novo campo profissional - a Etnomusicologia -, em esboço à época da definição de Adler mas na fronteira de sua cristalização no tempo da de Kunst. Adler, como fundador do campo musicológico como um todo, interessava- se pela música primitiva na medida em que partilhava a crença, generalizada na época, de que ela estaria nos primórdios da Música Ocidental. Por outro lado, Kunst foi um dos últimos grandes representantes do espírito da Escola de Berlim de Musicologia Comparada, responsável inclusive pela proposta do novo nome da disciplina, Etno-Musicologia (vide Kunst, 1950).

A sedimentação desse novo campo profissional constituiu-se em uma Etno-logia setorial, atinente à música. Isto deve ser entendido dentro do quadro das relações entre a Música e a Antropologia com o colonialismo e com a construção dos estados -nações modernos. Conforme já registrado, estuda rei isto adiante, por enquanto bastando dizer que a disciplina da Etno-musicologia deve aí ser abordada do ponto de vista de sua contribuição para a elaboração do binômio "nós"/"outros". Aqui, a temática da identidade do etnomusicólogo contrastiva com relação tanto à do músico e dos outros musicólogos quanto à do 
antropólogo e dos demais cientistas da área de Humanas - é de relevância fundamental.

Quando, em 1877, nos Estados Unidos, Thomas Alva Edison inventou o fonógrafo, tornando possíveis o registro e a reprodução sonoros, ele colocou ao alcance da nascente Musicologia Comparada não somente transcrições mais fidedignas e análises mais sólidas. Antes da existência deste aparelho - que só chega ao mundo da "música exótica" em 1889 -, transcrever este tipo de música era tarefa problemática, baseada na audição ao vivo ${ }^{8}$.

O que a gravação fonográfica colocou ao alcance da Musicologia Comparada não deve ser procurado, porém, somente no plano "técnico" da máquina, evidenciável pela sua intencionalidade material. Procurar só isto equivaleria a perder de vista seu modo de inclusão nos sistemas de relações sociais e de pensamento dessa Musicologia, bem como nos da própria Civilização Ocidental como um todo.

A gravação sonora parece constituir uma ideia arquetípica no Ocidente, explicitada enquanto projeto de conservação do som pelo congelamento (paralisação).

François Rabelais - este mesmo Rabelais que Lévi-Strauss (1969: 124-125) elegeu como fundador dos estudos de parentesco - narra no Pantagruel a passagem de sua expedição marítima por uma terra tão distante e de invernos tão frígidos que as falas e músicas congelavam antes de ouvidas. Aí, elas só podiam ser percebidas quando as pedras de gelo onde haviam sido gravadas eram aquecidas. O próprio Rabelais, pela boca de Pantagruel, vai buscar em Platão, Aristóteles, Antífanes da Trácia (século IV a.C.) e Plutarco de Queronéia (46-120 d.C.) a explicação para fenômeno tão maravilhoso, que, como temática, comparece frequentemente na literatura quinhentista italiana, tão especialmente fascinada com os Descobrimentos e na qual, aliás, Rabelais buscou muito de sua inspiração9 .

Essa ideia arquetípica, no Ocidente, da gravação fonográfica não parece se localizar, no entanto, tão somente na Antiguidade Clássica e no Renascimento. Ela encorpa-se com o decorrer do tempo, alcançando os inícios do século XIX. Aqui já se postula o fonógrafo (vide Gelatt, 1977; Read \& Welch, 1976), inventado afinal em 1877.

O que parece constituir o espaço específico do fonógrafo no pensamento que o construiu é a tentativa de supressão da distância e a intenção de reversão da lonjura em proximidade, para usar expressões e pensamento de quem já escreveu magistralmente sobre temática bem próxima - a da tele- visão (Heidegger, 1984: 249). No episódio do Pantagruel mencionado, os sons só gelam porque nos confins do mundo, no Mar Glacial, cujas ilhas são habitadas

${ }^{8}$ Foi com base na audição ao vivo que procederam Baker (1882), entre os índios Seneca, e Stumpf (1886), com os Bella Coola, ambos nos Estados Unidos. Este último texto é considerado por alguns autores como a primeira contribuição efetivarnente etnomusicológica, apesar de ainda não usar gravações fonográficas (Boilês \& Natriez, 1977: 29 ; Nettl, 1964: 14, 37).

9 Foi Tinhorão (198 1: 13) quem me chamou a atenção para este episódio pantagruélico. Para o texto de Rabelais, vide Moland, ed, (1950: 166-170). Quanto à literatura quinhentista italiana, Toffanin (1965). Entre os escritores italianos desta época, importantes para a temáti ca e conforme as indicações originais de Jacob, ed. (1845) [apud Tinhorão, 1981: 13], anoto Baldassare Castiglione e Celio Calgagnini. Sobre o primeiro, vide Carpeaux (1959, vol. I-A: 105-106) e Toffanin (1965). Sobre o segundo, Toffanin (1965). 
por bárbaros e monstros. Lá está, na sua desarticulação congênita, o inefável na distância tão distante que paralisa: o ex-ótico e o "ex-acústico"!

Mas, afinal, o fonógrafo - como o rádio, o cinematógrafo, a televisão, a máquina de retratos - consegue efetivamente reverter a lonjura em proximidade? Ecoando Heidegger (1984: 249), entendo que não. Pois a lonjura, mesmo que pouco extensa, é ainda lonjura, constituindo esta lonjura-perto que no campo da ciência vem a estabelecer a essência de seus objetos. O fonógrafo parece ter a ver com a objetivação da distância e com a "outrificação".

A história da aplicação do fonógrafo no terreno das musicologias é consistente com as ideias que levantei. Ele nunca ingressou no campo da Musicologia Histórica. E isto, não porque - pobre explicação - esta Musicologia estudaria a música do passado da Civilização Ocidental, quando ainda não havia a máquina e, portanto, gravações.

Não, o fonógrafo não adentrou na musicologia que tem por objeto a Música Ocidental por razões outras. Esta disciplina tem a partitura como centro de seu campo de investigações. A fonografia, consequentemente, é inadequada como intermediadora de seu objeto. Mas esta não é a razão substancial daquilo que aprecio. A substância de tudo está na crença, por parte dos praticantes desta Musicologia, na proximidade da música-objeto, a Música Ocidental. Da música; não, da partitura. Se a Música Ocidental é próxima - não está no Mar Glacial -, ela não constitui algo a ser "outrificado" e, portanto, nada de musicologia com relação a ela mas, isto sim, com sua partitura, espécie de fonógrafo (mas visual) seu.

O fonógrafo, pois (o auditivo), nunca ingressou no campo da Musicologia Histórica porque a Música Ocidental está "aqui mesmo" e, assim, gravá-Ia (para estudá-Ia) seria uma impropriedade imperdoável. Imperdoável porque é exatamente o movimento oposto aquilo de que necessita sua musicologia: lançá-Ia lá, "outra", através da partitura. Note-se, por outro lado, como o fonógrafo recebeu acolhida triunfal no âmbito da fruição da Música Ocidental, o que evidencia como esta música-fruída não é a mesma coisa que a coisa que ela é enquanto música-entendida.

Quanto ao Folclore Musical e às músicas folclóricas, o ingresso do fonógrafo em seu mundo só se dá a partir da década de vinte (Nettl, 1964: 16; Dahlback, 1958: 7); até esta época os estudiosos desse campo procediam como se aqui também fosse inadequada a gravação. Foi Bela Bartók quem postulou que, enquanto objetos científicos, as músicas folclóricas eram tão "estranhas" como a "mais primitiva" das "músicas exóticas". Desta maneira, a elas também deveria ser aplicada a fonografia. Mas não somente por "estranheza" é que essas músicas deveriam assim ser tratadas, transformando-se em objetos científicos legítimos. No raciocínio bartokiano (Bartók, 1981), era também estético o passe de ingresso das tradições musicais em consideração no campo da musicologia respectiva. Estético e também político: a postura de Bartók propugna pelo reconhecimento, dentro da universalidade da Música Ocidental, de uma identidade húngara, para ele tão Ocidental como as dominantes francêsa, italiana e alemã e só constituível a partir do folclore. Aqui - como também, 
algumas décadas depois, com relação à música popular -, fruição e entendimento numa só caixa: na "outrificação" de uns "nós" e na familiarização de alguns "outros". Tudo, no campo da Música Ocidental, o emblema excelente do concerto das nações.

As bases institucionais da Escola de Berlim de Musicologia Comparada foram lançadas em 1900, com a constituição do Arquivo de Fonogramas do Instituto de Psicologia da Universidade de Berlim. Este Instituto, dirigido pelo psicólogo, musicólogo e filósofo alemão Carl Sturnpf, era uma entidade das mais respeitadas no cenário da Psicologia européia da época, esta disciplina sendo então considerada como uma espécie de rainha das Ciências Humanas. A Psicologia praticada neste Instituto - interessada na investigação dos canais sensoriais -, embora francamente de base empírico-laboratorial, se contrapunha ao experimentalismo da de um Wilhelm Wundt'10.

Consistentemente com esta moldura, o projeto do Arquivo era estudar transculturalmente os processos mentais envolvidos na música, especificamente se interessando pela análise melódica e organológica. Por sua vez, esta análise melódica aí se centrava nas alturas (frequências) sonoras, sistemas de afinação e escalas.

O material fonográfico pouco a pouco reunido pelo Arquivo através de expedições realizadas pelo mundo inteiro constitui para a Musicologia Comparada não somente a base material de sua produção científica. Ele vem a substituir as sociedades e indivíduos que o originaram, resgatados por notas etnográficas, quer dizer, linguístico-culturais.

Esta Psico-Musicologia só vai se explicitar como disciplina etnológica através da filiação às ideias difusionistas e evolucionistas vigentes na época. Isto se concretiza através da colaboração de Erich Moritz von Hornbostel com o musicólogo berlinense Curt Sachs. Hornbostel foi aluno de Stumpf no Instituto e seu sucessor na direção do Arquivo. Por sua vez, Sachs - que viajara a Europa estudando as coleções organológicas de diversos museus etnográficos - tinha como questões fundamentais de seu interesse as origens da música e da dança e a classificação de instrumentos musicais (vide Sachs, 1947, 1953, 1962).

Da colaboração com Sachs é que provém, então, o acento etnológico porque originalmente psicológico - da Escola. No fundamental, a música aí é abordada a partir do estudo comparativo da origem e difusão de itens, traços e complexos, isto dentro da moldura da doutrina dos círculos culturais. Por outro lado, esta abordagem embebe-se das ideias evolucionistas de Darwin e Spencer, conforme elaboradas por Tylor e Frazer. Isto vem a sub meter o difusionismo da Escola à postulação de uma unidade psíquica da humanidade, esta por sua vez entendida nos termos da contenção de que os povos primitivos (os Naturvôlker) representariam estágios anteriores de desenvolvimento com relação aos europeus.

\footnotetext{
10 De Stumpf, além do já referido (1886), conforme o também conspícuo Tonpsychologie (1883, 1890). Sobre a importância de sua contribuição, vide Pinto (1983: 76-78) e Heidbreder (1964). Stumpf foi orientador, no Instituto, da tese de doutorado (sobre percepção acústico-tonal) de Wolfgang Kõhler, um dos futuros fundadores da Psicologia da Gestalt (Engelmann, 1978: 8).
} 
Enquanto, pois, Etno-logia, a Musicologia Comparada vai se caracterizar dentro do cenário da Antropologia de sua época. Ela não acrescenta originalidade a este quadro, aplicando-o automaticamente, como se o seu objeto - a música - nada tivesse de específico. Mas onde estará, então, para a disciplina tal especificidade, já que aí, no plano da inteligibilidade, isto nunca parece se evidenciar? Sugiro que ao nível da expressão sensível, quando, congelada a música nos minúsculos cilindros de cera em que se a capturava, pôde passar ela a ser ouvida, transcrita e analisada com o um exemplo.

Isto equivale a verificar que a Musicologia Comparada é a Musicologia Sistemática dos povos primitivos, cuja inteligibilidade se entrega à Etnologia e à Psicologia. Segundo Adler (1885) e, depois, Riemann (1908), a Musicologia Sistemática, oposta à Histórica, tem os "aspectos sonoros" da música como seu campo principal de investigação (Pinto, 1983: 70-73).

De Adler a Kunst, pois, a sedimentação do novo campo profissional redundou na construção sociologicamente efetiva de um objeto e no abando- no de intenções meramente pensáveis com relação a ele.

A leitura de Hornbostel (1982) dá ideia do que sumarizei. Esta obra é "musicológica" - referente ao que Merriam (1969) virá a chamar de som da música -, feita às expensas do material "etnológico" recolhido por KochGrünberg (1982) nas duas viagens que realizou ao noroeste amazonico no início do século. Este tipo de colaboração - entre "musicólogos" e "etnólogos" - veio a se tornar modelar para a Escola (Bose, 1972 e Schneider, 1952).

A característica central da obra em tela - produção paradigmática da Escola - é o divórcio entre as abordagens "musicológica" e "etnológica", a música ali (o som) sendo mera ilustração de ideias genéricas acerca dos povos primitivos:

Os resultados mais importantes a que contribuíram os fonogramas de KochGrünberg é que o canto de todos os índios, dos esquimós polares aos (habitantes) da Terra do Fogo, tem um caráter comum que o distingue claramente do modo de cantar de todos os outros povos (Hornbostel, 1982: $360-361$ ).

Esta, a característica dos cantos em análise, é genérica por excelência. Em seguida, Hombostel dirá que tal característica, além de genérica, é a única. Pois este caráter comum (dos "índios" por oposição a "todos os outros povos") é indiviso. Diz ele: "Da mesma maneira que é fácil e certo conhecer o caráter comum dos cantos indígenas, é difícil encontrar em cada tribo diferenças de estilo musical" (Idem: 363).

Mas por que toda esta generalidade? Responde o sábio, alegando que este caráter comum proviria "não do grau de desenvolvimento nem da cultura, mas da raça [... o que está arraigado] tão profundamente no fisiológico que dura por milênios" (Ibidem: 362).

Esta Musicologia, portanto, é inapetente para encontrar o diferente no seio daquele tão diverso do "nós" que ajudava a construir (o "outro"). Ela apenas quer nele conhecer o comum genérico, medida de sua projetada alteridade extrema - naturalismo "musicológico" somado a tautologismo "etnológico". Nos 
futuros som e cultura de Merriam, a representação, enfim, do diálogo surdo do "civilizado" com o seu projeto de "selvagem" - estados-nações e colônias.

A expansão que a Musicologia Comparada conheceu na Alemanha durante as três primeiras décadas deste século foi de grande magnitude. A partir do quadro fundador, o grupo foi se reproduzindo, no sentido do que a montagem de um sistema de ensino para a formação de egressos foi fundamental. As posições de emprego mais relevantes para a categoria encontravam-se no Arquivo de Fonogramas e na Escola de Música da Universidade, bem como na Coleção de Instrumentos Musicais e na Biblioteca Pública estatais de Berlim. O Arquivo e a Coleção desempenhavam papel hierarquicamente superior no conjunto, constituindo os locais de serviço ideal (Goode, 1969) para a disciplina, seus pontos ("mercados") por excelência de saída para o público ${ }^{11}$.

A reprodução do sistema foi tão potente que em 1930 foi criada a Gesellschaft zur Erforschung der Musik des Orients, cuja denominação mudou para Gesellschaft fiir Yergleichende Musikwissenschaft em 1933, data a partir da qual começou a Sociedade a publicar o seu órgão oficial, o Zeitschrift für Vergleichende Musikwissenschaft.

Wilensky (1970) mostrou como a criação de uma entidade representativa a nível nacional sintomatiza para uma nova profissão um passo importante no sentido de sua sedimentação. Tal entidade irá delimitar o novo campo com relação às áreas vizinhas, estabelecendo o perfil profissional legítimo para o desempenho das tarefas de seu quadro de trabalho. Isto vai trazer como consequência o discernimento entre tarefas centrais (o serviço ideal de Goode, 1969) e o dirty job, atribuído aos subordinados. Finalmente, a entidade vai intermediar os conflitos entre os velhos e os novos profissionais do campo, que apontam para a mercabilidade do novo trabalho e para as relações mantidas pelos profissionais com sua clientela.

A eleição, pela Escola, das quatro agências referidas como locais privilegiados de trabalho explicita duas estratégias cruciais: de um lado, o Arquivo e o Museu (com a Coleção de Instrumentos), levando à clientela a imaginação do "outro". De outro, a reprodução mesma de seus quadros: a Universidade e a Biblioteca. Respectivamente, estratégias pública e privada.

A ascenção do nazismo e a Segunda Guerra fulminaram a Musicologia Comparada na Alemanha. Já em 1933 - no mesmo ano, pois, do batismo definitivo da Gesellschaft für Vergleichende Musikwissenschaft -, fora criada em Nova Iorque a American Society for Comparative Musicology, Estatutariamente, esta última se definia como organização-filha da entidade alemã, cujos membros tinham inscrição automática na americana. George Herzog, na Alemanha um brilhante aluno de Hornbostel, foi membro do Comitê Organizador e da primeira e única Diretoria da entidade novaiorquina. Herzog,

\footnotetext{
${ }^{11}$ No sentido da presente reconstituição, servi-me das notícias e relatórios constantes dos números dos doze primeiros anos de Ethnomusicology; inclusive dos doze números iniciais de Ethno-Musicology Newsletter, editados por Alan P. Merriam de 1953 a 1957 e considerados como o primeiro volume de Ethnomusicology propriamente dito. Merriam editou também o segundo volume, do número 1 ao 3, publicado em 1958. David P. McAllester foi o editor seguinte, desde o número I do terceiro volume até o número 1 do sexto volume, de 1959 a 1962. Bruno Nettl foi o editor desde o número 2 do sexto volume até o número 3 do oitavo volume, de 1962 a 1964.
} 
acossado pelo nazismo, transferira-se em 1932 para os Estados Unidos, onde na Universidade Columbia foi estudar com Boas. A criação desta "regional" da sociedade alemã nos Estados Unidos fora uma providência tomada como tentativa de fortalecimento internacional da Gesellschaft, em dificuldades na AIemanha nazista: muitos de seus quadros eram judeus ou politicamente indispostos com o estado nacional-socialista. Isto se tornou insustentável nos anos seguintes, provocando a dissolução da comunidade na Alemanha, o que está simbolizado pela morte, em 1935 na Inglaterra, de Hornbostel.

Durante alguns anos, quadros norteamericanos como Charles Seeger, Helen Roberts, somados aos emigrados alemães - entre os quais, Herzog, Bukofzer e Kolinski -, tentaram dar continuidade à "regional". Era o tempo da Grande Depressão. Com a entrada dos Estados Unidos na guerra, as dificuldades se tornaram muito mais agudas para a organização. Esta, por outro lado, não se caracterizara como representante da comunidade etnomusicológica americana, ainda em embrião. Tudo isto provocou, em 1939, a extinção da Society.

Nos Estados Unidos, as origens da Etnomusicologia também remontam aos finais do século XIX, estando também ligadas ao arquivo fonográfico. Em 1889, o arqueólogo norte-americano Jesse Walter Fewkes - futuro diretor do Bureau of American Ethnology da Smithsonian Institution, em Washington fez, entre os índios Zuni e Passamoquoddy, as primeiras gravações fonográficas (em cilindros de Edison) de "música exótica" do mundo, transcritas e analisadas dois anos depois por Gilman (vide 1891).

Já no século XX e sob os auspícios do Bureau, Frances Densmore (1922, por exemplo) é um nome que merece menção especial. A ela se deve uma extensíssima produção, cuja relevância, durante muitos anos contestada por suposta superficialidade teórica, recentemente vem sendo reconhecida (Boilês \& Nattiez, 1977: 36-37).

Embora as portas de entrada das origens norte-americanas da Etnomusicologia tenham sido as do arquivo fonográfico, cabe reparar que aqui elas estão institucionalmente ligadas à Etnologia. Não à Psicologia, como na Alemanha. Uma Etnologia que muito embora - através de Boas - tenha incorporado o interesse psicológico, vai dialogar muito mais com a Linguística, a Antropologia Física e a Arqueologia (Hallowell, 1976).

O nome de Boas é congênito na direção da conformação da Etnomusicologia nos Estados Unidos. Detentor de um grande interesse pela música (vide 1955 e 1988), ele vai incluí-lo em sua atividade de professor. Boas foi professor de Kroeber e de Herskovits, respectivamente professores de Roberts (vide 1933, 1936) e de Merriam. Ademais, seguidor do pensamento de Stumpf quanto à música, ele vai se ligar também à posteridade norte-americana da Escola. Conforme disse anteriormente, Herzog, ao emigrar para os Estados Unidos em 1932, foi ser aluno de Boas em Columbia. Entretanto, Herzog aí não chegou 
sozinho: com ele, emigraram também os fonogramas do Phonogrammarchziv, as bases institucionais - como espero ter mostrado - da Escola ${ }^{12}$.

O desenvolvimento da Etnomusicologia nos Estados Unidos vai se ligar, então, à atividade acadêmica de Boas, estando montado, por outro lado, nos substratos fonográficos do Bureau e do Phonogrammarchiv. Pouco a pouco, isto vai se explicitar pela captura da disciplina - e pelo se deixar capturar desta pela Etnologia, da qual paulatinamente vai passar a constituir um sub-campo. Esta captura, entretanto, não é nunca completa pois a área continuará a manter seus vínculos com o círculo artístico-musical e com as musicologias em geral, seu quadro de vizinhança se integralizando pelas suas relações com o Folclore.

Este processo de conformação, que desabrocha nas décadas de 30 e 40 e que vai culminar nos anos 50, pode ser apreendido pelo exame das démarches em torno da nominação da disciplina. Pouco a pouco, a antiga Musicologia Comparada passa a ser chamada de Ethno-Musicology; com hífen. Note-se que no modelo de Adler, a Musicologia Comparada é comparada tão somente por oposição à Histórica, a primeira cuidando dos "primitivos", a segunda dos "civilizados". Ainda dentro deste modelo, a Musicologia Sistemática se evidencia pela abordagem dos aspectos físicos da música.

Sob a alegação, porém, de que comparar é tarefa de qualquer ciência, emergiu o novo nome do campo: Ethno-Musicology. O que parece estar implicado neste nome é, de um lado, a evidenciação do contraste Musicologia Comparada/Musicologia Histórica e, pois - em última instância -, a pertinência da área (enquanto musicologia) ao território da Música e, assim, ao círculo das Artes. De outro, o que está aí sendo dito é que a nova área é uma Etnologia setorial (atinente à música) e, desta maneira, também uma Ciência (Social). Esta última pertinência - científico-social - da Etno-Musicologia parece querer ser comunicada com o cancelamento, enfim, do hífen da expressão, o que só se dá, porém, em 1955, durante o 10 Encontro Anual da Society for Ethnomusicology (SEM).

O processo que culminou, em 1955, na fundação da SEM se fez em torno da criação de um mercado cada vez maior de bens e serviços e de prestígio, referente às "músicas exóticas" e folclóricas. A indústria fonográfica desempenha papel central neste mercado, o aparecimento de empresas como a Ethnic Folkways Records, com a sua célebre Ethnic Folkways Library (vide Menezes Bastos, 1993), sendo sintomático desta irrupção. Paralelamente a isto, a oferta de cursos na área em epígrafe - em departa- mentos de Música, Antropologia e Folclore e em bibliotecas, arquivos e museus - gradativamente vai multiplicando o grupo.

Os encontros anuais da American Anthropological Association (fundada em 1888) e da American Musicological Society (de 1948) vão, por outro lado,

12 Estes fonogramas ficaram inicialmente em Columbia University. Em 1948, Herzog transfe- riu-se para os Archives of Folk and Primitive (atualmente Traditional) Music de Indiana University, em Bloomington, tendo-os levado consigo. Aí, eles vão se ligar muito mais à área do Folclore. Sobre o emprego por Boas do pensamento musical de Srumpf - que ele contrapõe ao de Spencer -, vide Boas (1955: 341). Também Sachs - depois de uma passagem pelo hoje Museu do Homem, em Paris - emigrou para os Estados Unidos (em 1939), tendo ido trabalhar no setor de música da biblioteca da Universidade de Nova Iorque. 
cada vez mais incluindo temáticas etnomusicológicas. Agências de financiamento de pesquisa tradicionalmente usadas pela Etnologia, Musicologia e Folclore, pouco a pouco passam a incluir a Etnomusicologia como rubrica financiável. Correspondentemente a tudo isso, a produção bibliográfica do campo cresce aceleradamente. Junto com esta produção, quase sempre relacionada com a fonografia para fins de estudo e/ou entretenimento, a Etnomusicologia alça um vôo público cada vez mais vigoroso, tornando-se uma área acadêmica de relativamente alta visibilidade leiga.

Esse processo de sedimentação da Etnomusicologia vai registrar o aparecimento de alguns textos clássicos da disciplina. $\mathrm{Na}$ década de 50 aparecem os célebres Enemy Way Music (McAllester, 1954) e Music in Primitive Culture (Nettl, 1956), este último sendo o primeiro manual da área. A delimitação do objeto da disciplina e a apresentação de seus métodos e técnicas de pesquisa são temáticas prioritárias no período, isto juntamente com estudos que os apliquem. A Etnomusicologia aí se caracteriza pela abordagem de três tipos de música: oriental, folclórica e primitiva (Nettl, 1956 : 1). Nettl, um exaluno de Herzog, e assim um "neto" de Hornbostel, usa em sua delimitação os critérios da oralidade e/ou não-ocidentalidade das músicas-objeto, mantendo desta forma a criteriologia de Kunst, ao que acrescenta o discernimento bartokiano quanto às músicas folclóricas.

Apesar de todo esse crescimento, a Etnomusicologia nunca alcançou aquela autonomização profissional de que fala Freidson (1971), expressa pelo controle sobre seus meios e condições de trabalho e sobre o conteúdo dos mesmos. Esta autonomização lhe permitiria o monopólio do mercado que tanto ajudara a constituir e, assim, os ideais da auto-avaliação inter-pares e da imunidade a pressões externas (Larson, 1977). A inclusão da disciplina na Etnologia nunca conseguiu deslocar esta pro fissão em termos de seus sistemas de conhecimento e ensino. Aqui, ler-escrever música, mesmo que dos "outros" emblema do etnomusicólogo com relação ao etnólogo -, sempre foi algo em si mesmo exótico, lançado para as margens da disciplina. Isto quanto à pertinência etnológica e, pois, científica da Etnomusicologia. Com relação à sua qualificação musical-artística - indiciada pelas relações de contraste mantidas com a Musicologia Histórica -, o mesmo se deu: nenhum deslocamento nos sistemas de conhecimento e ensino musicais, onde a consideração sobre o "outro" - mesmo que através de uma escrita-leitura musical - sempre foi algo de remoto e estranho, remetido para o "ex-acústico" das origens.

As razões para essa não-autonomização da Etnomusicologia devem ser buscadas na concretude das relações sociais mantidas pela disciplina com a sua vizinhança e com a clientela do referido mercado de músicas "exóticas" e folclóricas. McAlIester (1963: 183-185), um relatório analítico do campo, publicado no número comemorativo dos dez anos da SEM ${ }^{13}$, agudamente 
aponta as três características básicas da fase de implantação da disciplina. Nesta fase,

1. a maioria dos etnomusicólogos encontra emprego em departamentos e escolas de música, em alguns deles já havendo majors específicos da área. $\mathrm{O}$ exemplo paradigmático aqui é o Instituto de Etnomusicologiada Universidade da Califórnia em Los Angeles . Dirigido por Mantle Hood, este Instituto é uma espécie de conservatório de "música exótica". Hood (1960) é mais um "descendente" da Escola - através de Kunst -, seu Instituto enfatizando a execução musical. Segundo McAlIester, esta Etnomusicologia "aplica- da" seria "pouco antropológica".

2. os projetos de pesquisa etnomusicológica são financiados através de agências ligadas à Antropologia. Entre esses projetos, McAllester faz menção especial ao de Lomax (1968) - o conspícuo Cantometrics -, que se realiza sob a égide do Departamento de Antropologia da Universidade Columbia, com o suporte de Margaret Mead. Entre as razões apresentadas pelo autor para essa tendência - marcada por uma forte "ênfase antropológica" -, está a de que, nesta época, as fundações nacionais (como o National Institute of Mental Health) financiarem muito mais as ciências do que as artes.

3. o que dá mais prestígio - sucess, conforme McAlIester, este nativo tão diligentemente reflexivo - ao etnomusicólogo é interrelacionar as áreas matrizes da disciplina. Entre os exemplos citados pelo autor, de maximiza- ção deste sucess, figura o de Indiana University em Bloomington. Aí, a colaboração entre os departamentos de Música (através de Walter Kaufmann), Antropologia (Merriam) e os Archives of Folk and Primitive Music (George List) é caracterizada como extremamente significativa.

Este quadro norte-americano da década de 50 e começos da de 60 sintetiza de maneira aguda a essência do projeto etnomusicológico. Caso se queira remetê-lo aos tempos arquetípicos da Musicologia Comparada, a Etnologia deve ser vista como uma transformação da interface Psicologia- Etnologia.

O que o quadro em consideração revela é que a Etnomusicologia, apesar de todo o seu crescimento, é um campo sociologicamente ambíguo. De um lado, ela tem pertinência artístico-musical. Mas aqui ela é por princípio um paradoxo, pois procura, como logia que intenciona ser, a inteligibilidade dentro da quadra - a Arte - atribuída no Ocidente ao sentir. Isto ela ainda mais extremiza quando, enquanto também "parte" da Antropologia (uma Ciência Social) que aspira ser, vai buscar esta inteligibilidade no social (dos éthney). Mas a música, sua âncora mais funda, está no território que o pensamento Ocidental consagrou ao indivíduo ou - quando ao social - sempre à sua sensibilidade, nunca à inteligibilidade sua. Ademais, este social que a Etnomusicologia busca não se encontra no terreno do familiar (do "nós "), mas no da extrema alteridade, paradoxo que arremata a natureza ambígua da inclusão musical-artística da disciplina ${ }^{14}$.

14 Spengler (1973: 140-187) e Toynbee (1963: 275-277) - referências que levamo a partir de Carpeaux (1977:9) -, numa linha de reflexão compatível com a de Dumont (1970: 3-16 e 1985: 11-7 1), evidenciaram esta devoção da Arte, especialmente da Música, à ideologia individualista Ocidental. Particularmente, quando referida ao Grande Indivíduo, 
No plano de sua primeira inclusão (musical-artística), portanto, o que se verifica é que o etnomusicólogo constrói a sua identidade manipulando emblemas marginais à área inclusiva. Desta maneira, ele como que despreza o artista que quase é - músico - pelo cientista social - antropólogo - que quase será.

Enquanto disciplina antropológica, por outro lado, a Etnomusicologia vai se caracterizar como área subordinada. Esta assimetria se constrói a partir da estratificação de autoridade científica (Ritzer, 1971) ou, na acepção de Bourdieu (1983), da acumulação diferencial de capital científico vigente na comunidade antropológica entre - diga-se assim - "antropólogos gerais" e etnomusicólogos.

O recurso envolvido neste processo de estratificação é a inteligibilidade da totalidade sócio-cultural, especificamente desta enquanto etno. A música, reduzida ao som, aqui sempre será um "particular" ou "específico", espécie de exemplo ou ilustração da cultura e da sociedade, territórios epistêmicos monopolizados pelos "antropólogos ge(ne)rais". É exatamente este sistema de relações inter-societárias assimétricas (Cardoso de Oliveira, 1976: 54-58) que constitui o dilema etnomusicológico, manifestação regional daquilo que denominei de paradoxo musicológico. Trata-se, o dilema, do cerne da cultura etnomusicológica, uma cultura onde a música é fonografia, isto é, pura sensorialidade cuja inteligibilidade nunca é semântica mas pragmáticocontextuaI. Por outro lado, a totalidade desta cultura - a cultura e a sociedade -, excludente da música (som), é do tipo funcional: ela, na verdade, não passa de uma parte arbitrariamente privilegiada.

Apesar de toda a aspiração científica da Etnomusicologia, da qual Merriam foi o mais brilhante apóstolo, ela nunca conseguiu apropriar-se do recurso mencionado, a inteligibilidade da totalidade sócio-cultural da música. Isto representaria a concretização daquilo a que venho chamando de plano de intenções do projeto etnomusicológico e que Becker (1970) aproxima enquanto a dimensão simbólica de uma profissão. Tal recurso permanece monopolizado, como disse, pelas categorias localizadas no centro ("geral") do sistema antropológico.

A que tanta ambiguidade etnomusicológica vis à vis um tão grande crescimento? Esta indagação parte do pressuposto de que o etnomusicólogo, dentro de seus sistemas inclusivos - Música e Antropologia -, só atua com relativa autonomia naquele interstício que se explicita como o "som da música dos outros ". Mas, aqui, dois Cavalos de Tróia, da Ciência e da Arte, sempre a contestar a disciplina: "não entendo nada de música"; "a música não se explica, se sente"15. A que o paradoxo?

A ambiguidade em toque - que enlaça a Ciência e a Arte - torna possível uma grande margem de manobra na direção do crescimento da Etnomusicologia. Isto responde, por sua vez, ao crescimento do mercado de

herói ou gênio. Quanto à vocação social-sensível da música no Ocidente, conforme a tradição estético-filosófica que remonta a Filolau, Platão e Aristóteles. Vide a terceira parte deste texto para os dois tópicos.

15 Sobre a primeira frase feita, vide Menezes Bastos (1986a). As frases em consideração - verdadeiros provérbios quanto à disciplina - são praticamente sinónimas: ambas apontam, de um lado, para a negatividade do entendimento musical e complementarmente para a positividade sentimental-afetiva a respeito da música. 
músicas "exóticas" e folclóricas, mercado este que aponta para as relações com a clientela do sistema. O etnomusicólogo, nas suas relações com o "antropólogo geral" - controlando o som da música -, manipula algo do domínio antropológico (o "outro"). Correspondentemente, naquelas que mantém com o músico e com os musicólogos - especialmente com o "histórico"-, administrando algo sobre o "outro", assenhora-se de parcela do mundo musical atinente à inteligibilidade da música. Um camaleão, o etnomusicólogo: músico entre antropólogos e vice-versa! Isto lhe permite apropriar-se de recursos aqui e ali ao mesmo tempo. Esta a sua mercabilidade, instrumental daquela do mercado de "música dos outros" que tão bem intermedia, mercado este que o que vende são identidades. É nesse mercado enfim, que está a racionalidade tanto das separações quanto das uniões entre Etnomusicologia, Música e Antropologia.

Merriam é o clássico por excelência da Etnomusicologia. Co-fundador da SEM, primeiro editor de seu órgão oficial, Ethnomusicology - desde os tempos de Ethno-Musicology Newsletter -, presidente (196 1-1963) e ocupante de todos os postos relevantes da Sociedade, ele representa o espírito de cristalização da profissão, sendo o primus inter pares na arte de, conforme o lúcido apontamento de McAllester (1963: 183-185), fazer a ponte entre a Antropologia e a Música. Neste seu movimento, Merriam vai se caracterizar como o príncipe dos etnomusicólogos, o intelectual que encarna a vontade - e os valores - do grupo em questão (Gramsci, 1968).

Músico (clarinetista) graduado em 1948 em Northwestern University, ele chega à Antropologia através de Herskovits e de Richard A. Waterman, dois anfíbios quanto à Música e a Antropologia. Nesta universidade, Merriam se doutora sob a orientação do primeiro, com uma tese versando a música dos cultos afro-baianos (Merriam, 1951) ${ }^{16}$.

A herança do espírito da Escola está transparente na obra de Merriam, o que especialmente seu estudo sobre a música dos índios Flathead (1967) traz à luz. Aí, inspirando-se em Kolinski $(1936,1949,1959)$ e Herzog $(1935,1949)$ dois dos já comentados emigrados -, e retomando a acusmática de Hornbostel, nas conclusões (: 330) gravemente indaga:

\begin{abstract}
A que conclusões podemos chegar sobre a música Flathead e os resultados da aná lise descritos nas páginas anteriores? O ouvido, sozinho, nos diz que quase qualquer canção Flathead que ouçamos é Indígena Americana, por oposição, por exemplo, à música Africana. Ademais, ela é claramente identificável como música Indígena Nane-Americana, por oposição à Sul-Americana e é justamente tão claramente da Planície quanto se opõe, por exemplo, aos estilos Esquimó ou do Leste. Tudo isto pode ser verificado através do ouvido e a análise da música o confirma especificamente, ponto por ponto.
\end{abstract}

Nesta indagação, tanto a continuidade quanto o salto do Kulturkreis (círculo cultural) à culture area (área culturaly): do macro e largamente conjetural ao mediano e pontualmente verificável. Aí, o ouvido é o instrumento de testagem, a análise da música o epifcnomenizando. Adiante, Merriam (330) coloca em perigo seu próprio modelo conceitual: 
O ouvido não nos diz, no entanto, se uma canção desconhecida é uma canção Flathead, por oposição a uma canção Blackfootou Crow; a análise nos dá a resposta a esta questão?

Apesar de reparar que a comparação seria impossível, devido à falta de estudos sobre a música de outros grupos indígenas da Planície compatíveis com o seu sobre os Flathead, Merriam (330) responde a si mesmo:

A análise nos mostrou, entretanto, que a música Flathead não pode ser tratada como um todo e que não é significativo confundir a configuração diversa dos vários subgrupos de canções para alcançar uma "canção média " Flathead.

Pouco adiante, Merriam (331) arremata: "Isto é, a música Flathead é claramente da Planície; tanto o ouvido quanto a análise confirmam isto".

O que a música aqui faz - e ouvido e análise são os meios "fonográficos" nesta direção - é somente exemplificar, testemunhando a veracidade (culturalista) do instrumental conceitual pré-existente. Este, sim, é o "geral" de tudo. Note-se que canções desconhecidas constituem para Merriam - como para Hornbostel (1982: 363) - um grande perigo. O que serão estas canções senão aquelas que - apesar de audíveis e analisáveis - não estão pré-classificadas dentro de uma "área cultural", sendo simplesmente canções e, não, exemplos?

Buscando a identidade da música Flathead, Merriam (331) deixa-se, afinal, vencer pela tautologia, colocando-a, ademais disto, nos próprios índios:

Poderia um índio Flathead, por si mesmo, apontar sem erros as canções Flathead de uma amostra mista a ele apresentada? Esta é uma pergunta complexa, pois envolve critérios outros, além dos estritamente musicais. Os Flathead não abstraem sua música, enquanto música, do seu contexto [...]

O que será neste texto a música enquanto música senão, em sua estrutura musical, o "som" pantagruélico congelado, extirpado de quem o gerou e condenado ao contexto, ou seja, à música enquanto cultura? E o Flathead, que Homo será? Como "nós", que no show não conseguimos abstrair a música da cerveja?

No enfrentamento de todo este paradoxo, aposição de Merriam, longe de passiva, é dramática, resumindo os valores mais caros da profissão. Tal dramaticidade, presente nos germes originais de pensamento do projeto etnomusicológico, está especialmente manifesta em seu clássico, The Anthropology of Music (1964), seu trabalho teórico por excelência. Aqui, o paradoxo e o esforço para supera-lotransparecem com rigor extremo.

Este livro de Merriam explicita a cristalização da Etnomusicologia nos anos 60. Causador de um grande impacto no meio etnomusicológico, ele também atinge o inclusivo sistema antropológico, o que especialmente uma resenha no Current Anthropology (Merriam et alii, 1966) deixa claro.

Procurando definir a tarefa do etnomusicólogo como "o fazer ciência sobre a música", ele se pergunta:

A etnomusicologia, então, é uma ciência social ou uma humanidade? A resposta é que ela pertence aos dois (campos); sua abordagem e seus objetivos são mais científicos que humanísticos, enquanto que seu objeto (subject marter) é mais humanístico que científico (Idem, 25). 
Esta dupla pertinência da disciplina - nos planos do sujeito e do objeto não se coloca para o autor como de natureza genérica; pois "o etno- musicólogo procura criar sua própria ponte entre as ciências sociais e as humanidades" (25).

Desta maneira, para Merriam, a Etnomusicologia não é uma soma óbvia mas uma construção original. Nesta direção, no entanto, há barreiras a superar, decorrentes das inadequações existentes entre os dois continentes (18).

Merriam intenta superar estas barreiras com o recurso ao conceito de cultura. Para ele, cultura é "o comportamento humano aprendido e acumulado" (12).

Para Merriam, então, o que será a música? -"um produto do homem e tem estrutura, mas sua estrutura não pode ter existência em si mesma, divorciada do comportamento (cultura) que a produz" (7).

Aí, o rigor do paradoxo: como se aproximar de uma linguagem se ela, apesar de ter estrutura - isto é, um plano de expressão, com níveis fonológico e gramatical (Lyons, 1974a: 53-98) - e comportamento - sua realidade contextualpragmática -, está extirpada de conteúdo? Tem texto, contexto mas, contrariamente a toda evidência empírico-indutiva, nada "envia"? Sua estrutura, portanto, não será social, para retornar a Mauss (1979: 118), cuja lucidez tenho tentado tomar emprestada desde o início? Será que neste congelamento da música na "fonografia" não estará enigmaticamente também congelado o indivíduo Ocidental? Assim como a Esfinge que, se decifrada revertida ao social -, rolará montanha abaixo, invertendo o que ocorrerá ao Édipo, que também rolará mas para cima? Será, enfim, que neste enigma de Merriam, representado pela sua célebre definição da Etnomusicologia como "o estudo da música na cultura" (7), não estará a manifestação regional etnomusicológica do paradoxo musicológico, este sendo a expressão científica (das musicologias) do modo de inclusão da música no pensamento Ocidental?

O problema da Semântica Musical resume-se na possibilidade da evidenciação das transformações operadas pelo nativo entre expressão e conteúdo, Blacking (1977: 108) se referia a este como o problema por excelência da descrição etnomusicológica. Dispor que a música ("som") não "envia" senão "ela mesma" ("som") é lutar contra toda evidência empírica, universalmente verificável. Afinal, a música extrai a sua universalidade a partir do fato de, ocorrendo em todas as sociedades humanas, ser específica com relação a cada uma destas. Não há a música mas músicas, seu entendimento como "linguagem universal" constituindo uma construção Ocidental, concorrente para a ereção do paradoxo musicológico"17.

\footnotetext{
17 A música, sintomaticamente, está ausente do episódio da Torre de Babel (Gen. Xl: t-9). Aqui, Deu s pune os descendentes de Noé com a diferenciação linguística, sinal da diferenciação étnica. A identidade humana primordial já estava, é claro, dada: pelo trabalho, através do qual o homem se divertia, isto é, se tomava diverso dos outros seres (Menezes Bastos, 1983). Após o pecado original, esta diversão se torna uma tortura (conforme o Latim Vulgar tripaliare, original de trabalhar [Menezes Bastos, 1983). Na tradição bíblica, o lugar da música é a comunicação com o sagrado, esta sendo a competência primor- dial da Salmodia , posteriormente abraçada pelo Gregoriano. A teoria clássica grega da música que, junto com a Salmodia judaica. está na base do Gregoriano, na sua elaboração católica pro cura afastar o social da inteligibilidade, direcionando-o para a sensibilidade. Do outro lado da tradição bíblica, a música ocupa -se da sedução do homem com relação às mulheres, Os Cantares (O Cântico dos Cânticos de Salomão) são aqui arquetípicos.
} 
A questão referente ao tipo de semanticidade da música - se referencial ou de sentido, afetiva ou cognitiva - não deve ser confundida com a problemática mesma de sua semanticidade. Tal confusão, muito comum nas diversas musicologias, está na base da negativa de conteúdo à linguagem musical.

Partindo do princípio de que o projeto de uma Semântica Musical se centraliza na problemática do deslindamento das transformações inconscientes levadas a cabo pelo nativo entre expressão e conteúdo, seu encaminhamento passa pelo equacionamento das seguintes questões:

1. quais as categorias, definidas em termos de observáveis, operadas nestas transformações?

2 . quais as operações, estabelecidas no plano da redutibilidade, que sofrem estas categorias no processo de transformação em referência?

3. as categorias e operações acima se simplesmente não devem reproduzir o senso comum - sempre ad hoc quanto ao universo estrutural das regras -, por outro lado não podem deixar de ser aplicáveis ao mundo das evidências empíricas nativas.

As duas primeiras questões dizem respeito à adequação operacional de uma teoria semântica, a última apontando para a sua adequação material (Lyons, 1974b). Subjacente a ambos os tipos de questão, está a problemática do "envio" musical, que assim pode ser rapidamente esquematizada: dada uma determinada estrutura fonológico-gramatical - minimamente, um motivo - qual o seu correspondente no plano semântico - tipicamente uma axía (valor) - e vice-versa?

Quando Merriarn define a tarefa da Etnomusicologia como "o estudo da música na cultura", identificando a música (estrutura, nas suas palavras) com seu plano de expressão (fonologia e gramática) e a cultura (ou comportamento) com o contexto, ele, possivelmente em busca de uma Semântica, instala-se no campo de uma Pragmática, espécie de Sócio-musicologia.

Parte ele, pois, do princípio de que a música (som) está fora da cultura, não constituindo, pois, comportamento social. Se a música não é social - mas individual, como a ideologia Ocidental a estabelece, indecifrável -, cabe à Etnomusicologia removê-la das Humanidades e lançá-la na área da Ciência (Social), território da cultura e do social. Assim fazendo, Merriam de um lado separa, isto é, categoriza. De outro, porém, esteriliza-se nesta separação, nunca alcançando reduzir os dois mundos de sua música. Finalmente, tentando distanciar-se do senso comum, Merriam dele se inunda, reproduzindo a ideologia individualista Ocidental sobre a música. Mesmo a sua SócioMusicologia - sua Pragmática Musical, que é de resto a sua Etnomu- sicologia também não pôde ir muito adiante, o que é a medida mesma da diluição posterior de seu pensamento.

Quando, entretanto, nove anos mais tarde (circa, 1973), Merriam reconceitua a disciplina como "o estudo da música como cultura" (1977: 204), ele aponta para uma ruptura em seu próprio pensamento, abrindo uma brecha para uma verdadeira Semântica. Na primeira dessas duas definições, o que se verifica é uma busca do sentido substituída pelo achamento do uso. Na segunda, 
entretanto, a perspectiva de uma chave: o sentido da música como algo socialmente codificado em sua estrutura, que deixa de ser um fétiche.

Infelizmente, Merriam não teve oportunidade de levar adiante esta fina síntese, vitimado que foi, poucos anos depois, por uma morte tão inesperada e brutal. De qualquer sorte, de seu tão profundo esforço, um salto bem adiante de uma pobre interligação da Música (e música) com a Antropologia (com a cultura), salto na direção de uma Musicologia Com Homem - uma Antropologia Com Música -, obstinada tarefa para talvez mais um século de trabalho.

Se a Etnomusicologia se cristaliza nos Estados nos anos 60, a partir daí o que ocorre com ela? Note-se que por cristalização entendo a normalização (Kuhn, 1975) da disciplina em torno do paradigma (Kuhn, 1975) dilemático.

Cristalizada a Etnomusicologia, o que os anos seguintes vão mostrar, até a década de 80 , é a diluição de seu paradigma. Isto propicia um incremento impressionante do campo: sistema de ensino, mercado de empregos, financiamento à pesquisa, publicação (biblio-disco-filmográfica). O crescimento da SEM pode evidenciar isto: em 1981, ela totaliza 2.191 membros (Stone \& Cassei, 1986: 2), muitos e muitos adiante das 24 pessoas que, durante o $54^{\circ}$ Encontro Anual da American Anthropological Association (em Boston, 1955), se reuniram para discutir a possibilidade da fundação da Sociedade (C. Seeger, 1956: 3$)^{18}$.

Note-se que o período em referência caracterizou-se por um espantoso boom da indústria cultural norte americana, especialmente significativo no âmbito das músicas "exóticas" e folclóricas. Estas músicas agora são o objeto de um cada vez mais importante setor da indústria fonográfica, radiofônica, televisiva e do show business em geral (Menezes Bastos, 1993).

Correspondentemente a este boom, nota-se a utilização cada vez mais constante de elementos e processos empregados nessas músicas na elaboração das músicas urbanas norte americanas. Estas, por sua vez - no eixo jazz-rock sofrem um processo de difusão internacional sem precedentes, o que vem a tornar esta música popular numa espécie de terceiro kathólon ("universal") musical do Ocidente (o primeiro foi o Gregoriano, o segundo a Música Ocidental dos séculos XVII-XIX).

Paralelamente a tudo isto, vive-se nos Estados Unidos uma época de explosão da questão da etnicidade, com a constituição de movimentos sociais que, reivindicando direitos civis, encontram na música o elemento culturalexpressivo por excelência diacrítico de construção das raízes, signo crucial da procurada alteridade.

No plano propriamente epistêmico da Etnomusicologia, a música popular - antes um tema residual - é incorporada como objeto legítimo. Este deslocamento tem a ver com o similar ocorrente no campo inclusivo da Antropologia, sob a égide de sua "moderna crise" (Lévi-Strauss, 1962).

Apesar de todo esse crescimento - et pour cause -, o paradigma dilemático não parece sofrer perturbações, senão em função de anomalias (Kuhn, 1975)

18 Para uma visão deste processo de crescimento, vide McLeod (1973: v-vi), Béhague (1975: iv), Rice (1983: v) e Etzkom (1985: 395-396). 
nas áreas de juntura que a disciplina mantém com as outras musicologias. Isto parece constituir uma perspectiva nova no ar: a da programação de um corpus scientiarum musicarum que, atravessando as musicologias, penetra nas Ciências Humanas inclusivas e nas Humanidades. Chase (1976) - inspirado em Lévi-Strauss (1970) - e C. Seeger (1977) estão na base desta perspectiva, cultivada também por Blacking $(1977,1983)$, Nattiez (1975) e Feld $(1982,1984)$. Fora do campo etnomusicológico, Imberty (1979, 1981) - um psicólogo da música - e Shepherd (vide Shepherd et alii, 1977) - sociólogo - constituem dois exemplos importantes da tendência.

A perspectiva globalizante é dominante nesses autores, deixando de aqui haver, portanto, musicologias tópicas definidas a partir dos tipos musi- cais "primitivo", "folk", "popular" etc. Por outro lado, estrategicamente busca-se agora a superação do clássico quebra cabeças (Kuhn, 1975) etno-musicológico o seu dilema tradicional -, que, como tentei evidenciar, sempre equivaleu à negação de semanticidade à música. Em suma, a perspectiva em consideração parte do princípio de que a música é um sistema significante pleno.

Essas transformações no paradigma dilemático da Etnomusicologia configuram uma crise (Kuhn, 1975) do mesmo que se relaciona com deslocamentos correspondentes nos campos inclusivos da Antropologia e da Música. Dos anos 70 em diante, se a Antropologia (alguma Antropologia) consagra também para si características tradicionalmente mais da Arte do que da Ciência (conforme exemplarmente Geertz, 1978), no âmbito da Música (também de alguma), o que se passa é o inverso: a "cientifização" da Arte (Boulez, 1972). Rompe-se aí, portanto, a biunivocidade entre sensibilidade e inteligibilidade com relação respectivamente à Arte e à Ciência. Paralelamente a isto, o "outro" já não se contém nos confins do "mundo civilizado", uma espécie de boomerang parecendo aqui atuar com relação ao quadro clássico colonialista: as antigas metrópolis são invadidas por grandes contingentes populacionais de suas ex-colónias.

Para uma Antropologia das outras musicologias

\section{Interfácio}

A fazer sentido meu quadro interpretativo, se a Etnomusicologia nos termos do paradigma dilemático constitui o paradoxo musicológico no instante de atenção ao "outro", as demais musicologias, aquelas cujos objetos são as músicas Ocidentais, deverão estabelecer o dito paradoxo quanto ao "nós". Afinal, as musicologias são subsistemas do sistema instituído pelo pensamento Ocidental sobre a música. Desta maneira, a ordem vigente para o caso da Etnomusicologia não pode simplesmente ser uma ordem tópica e especial. Ela deve ter caráter típico quanto ao apontado sistema: se há ordem em algum lugar, deverá também havê-Ia, transformada ou não, nos outros similares. 
Mas, afinal, para aonde aponto ao dizer musicologias?

$\mathrm{O}$ termo musikalische Wissenschajt (ciência musical; depois Musikwissenschaft [ciência da música]) foi usado pela primeira vez em 1863 por Karl Franz Friedrich Chrysander (1826-1901) quando da fundação do Jahrbucli fur Musikalische Wissenschaft. Com esta expressão, Chrysander pretendeu indicar uma nova ordem nos estudos de História da Música e de Teoria Musical. Esta ordem estabelecia que a música do passado deveria ser editada e executada rigorosamente conforme o espírito de sua época e locus de sua criação.

$\mathrm{O}$ que esse handelista notório assim intentava era uma ruptura com a tônica daqueles estudos em seu tempo, profundamente colada a uma estética do presente. Desta maneira, a uma visão da originalidade nos termos do intérprete, Chrysander preferia uma abordagem no plano do mensageiro, ou seja dos modelos nativos daquela música do passado. É desta forma que a partitura crítico-interpretativa, finalidade da nova ordem de investigação proposta por Chrysander, se caracteriza como uma etnografia. Uma etnografia, porém, onde o canal musical - e, não, lingüístico (conforme visto supra) - é prevalecente.

A criação, portanto, do termo Musicologia, na segunda metade do século XIX, parece apontar para um movimento na direção da própria invenção do objeto música do passado. Este começa a gesticular já no século XVIII, através da inclusão no repertório das execuções musicais - públicas e das cortes - de peças de compositores não-contemporâneos. Antes disto, estas compareciam inexplícitas nas execuções, tipicamente como "temas" de peças atuais.

Este novo modo de ouvir o passado - como "outro" - só parece consolidarse, entretanto, no final do século, em 1885 e arredores. Nesta data, Chrysander, juntamente com Guido Adler (1855-1941) e Philipp Spitta (1841-1894), fundam o Vierteljahrsschriftjür Musikwissenschaft, no primeiro número do qual Adler (1885) - conforme estudado -, além de oferecer a primeira definição de Musicologia Comparada, também administra conceituações para a Musicologia Histórica e Sistemática, isto num quadro de organicidade epistêmica sem precedentes.

A Musicologia, pois, nasce sistematicamente no plural, enquanto musicologias. E isto, de dentro do território da Música, do círculo artísticomusical, especificamente de sua prática de execução: para o músico e o aficcionado, a Ciência parece então ser algo de muito sério para se deixar nas mãos somente dos cientistas.

O termo musicologias começa a fazer sentido, como o conjunto de três (a rigor, dois; conforme adiante) sub-campos oriundos do círculo artísticomusical. Isto, devido a uma ruptura com relação aos discursos da História da Música e da Teoria Musical.

Os referidos subcampos são a rigor dois, e não três, pois a Musicologia Sistemática não constitui uma área específica da mesma ordem das Musicologias Histórica e Comparada. Ela é muito mais uma abordagem interessada nos aspectos "sonoros" (fonológico-gramaticais) da música -, presente nestas. 
Mas, e o que dizer da Psicologia e da Sociologia da Música, bem como da Estética e do Folclore Musicais?

Quanto à Estética Musical, sua localização é o continente filosófico, sendo que sua consolidação desponta a partir de Kant (1961). Neste continente, a Estética Musical encontra uma irmã gêmea na Filosofia da Arte (Música), discurso que encontra sedimentação na Estética de Hegel (1974).

Enquanto à Estética Musical cabe o estudo do Belo, à Filosofia da Música é devida a análise das relações intercontextuais da música com os demais sistemas sócio-culturais. Por motivos utilitários e apoiado em F. Menezes Bastos (1987: 10-11), verei estes dois sub-campos filosóficos como reunidos numa só e única musicologia, que chamarei de Estética Musical.

Adorno (1983a: 259) assevera que a Sociologia da Música é tão somente uma "das diversas sociologias de alguma coisa". Isto sintomatiza que no campo sociológico o objeto "música" não se encaixa de maneira especial, mas típica. Consistentemente, os praticantes da Sociologia da Música - diferentemente dos musicólogos comparados (no futuro, etnomusicólogos) e históricos - isto o são enquanto sociólogos "gerais". Não parece aqui ter vigência, assim, uma identidade incluída de "musicólogo" e, desta maneira, de "músico". Isto, desde Comte a Becker, passando por Weber e Adorno.

A Sociologia da Música não procede, pois, do círculo artístico-musical mas sociológico. Compativelmente, nunca fez sentido aqui a busca de autonomia quanto ao objeto "música", o que - conforme adiante - sofrerá profundas mudanças, porém, a partir dos anos 70.

O caso da Psicologia da Música é semelhante ao da Sociologia da Música: trata-se de uma Psicologia de qualquer coisa feita sobre a coisa musical. Há duas contenções, porém, aqui: a Psicologia da Música resulta ser, numa só caixa, uma Psicologia e uma Psicanálise da Música, conjunção extraordinária na medida em que uma Ciência Humana (a Psicologia) e uma sua "contra-ciência" (a Psicanálise) [Foucault, 1985] se encaixam num mesmo espaço epistêmico. Segunda contenção: o que poderia ter vindo a ser uma específica PsicoMusicologia concretizou-se como Musicologia Comparada (depois, Etnomusicologia), conforme estudei. De acordo com o que trabalhei, esta transmutação do "psico-" no "etno-" foi tornada possível pela migração dos quadros alemães (e dos fonogramas!) para os Estados Unidos.

O Folclore Musical, como musicologia, partilha com o campo folclórico inclusivo muitas ambiguidades. Isto já está sinalizado pelo fato de as expressões que lhes dão título apontarem simultaneamente para as disciplinas e seus objetos. Por outro lado, estes objetos são reivindicados pelo menos pela Antropologia e Sociologia, com suas respectivas musicologias. Foi exatamente este tipo de reivindicação que permitiu à Etnomusicologia, a partir dos anos 30, apropriar-se do estudo das músicas folclóricas, alcançando uma importante expansão. Finalmente, a profunda e explícita imbricação tanto das disciplinas quanto de seus objetos com a emblemática da construção das identidade dos estados nacionais parece especialmente estigmatizar a academicidade do Folclore e de sua potencial musicologia. 
As musicologias, pois - para resumir -, constituem subcampos epistêmicos cuja existência advém de quatro grandes círculos: Música, Ciências Humanas, Filosofia e Folclore.

De dentro do primeiro continente (Música), nasceram, na segunda metade do século XIX e a partir de ruptura nos discursos da História da Música e Teoria Musical, a Musicologia Histórica e a Musicologia Comparada (futura Etnomusicologia), sub-áreas às quais a expressão musicologia tem adequação estrita.

Do segundo círculo (Ciências Humanas), provêm a Psicologia - neste caso, adjunta à Psicanálise - e a Sociologia da Música, também com a datação inicial do século XIX. Do terceiro (Filosofia), a Estética Musical (aqui reunida à Filosofia da Arte-Música), a partir do século XVIII (Kant) e XIX (Hegel). Estas três musicologias são especializações temáticas - sem autonomia - dos continentes matrizes. O termo musicologia tem emprego lato agora.

O Folclore Musical completa o quadro das musicologias, sob o signo de uma especial ambiguidade e falta de soberania. Tratarei dele como reuni- do à Musicologia Comparada (Etnomusicologia).

As relações das duas primeiras musicologias com as Ciências Humanas correspondentes (Etnologia e História) têm duas mãos: no sentido MúsicaCiências Humanas, busca de legitimidade com relação à explicação da totalidade sócio-cultural (inteligibilidade). No sentido inverso: procura de ilustração e exemplo sensíveis.

O limite temporal superior deste quadro são os anos 6o, quando se insinua a possibilidade daquilo a que poder-se-ia chamar de "estudos musicais", um corpus scientiarum musicarum transcontinental em termos disciplinares.

O binômio "som"/"cultura" constitui o nexo fundamental do quadro em análise, a seu respeito podendo-se divisar o seguinte contínuo das musicologias:

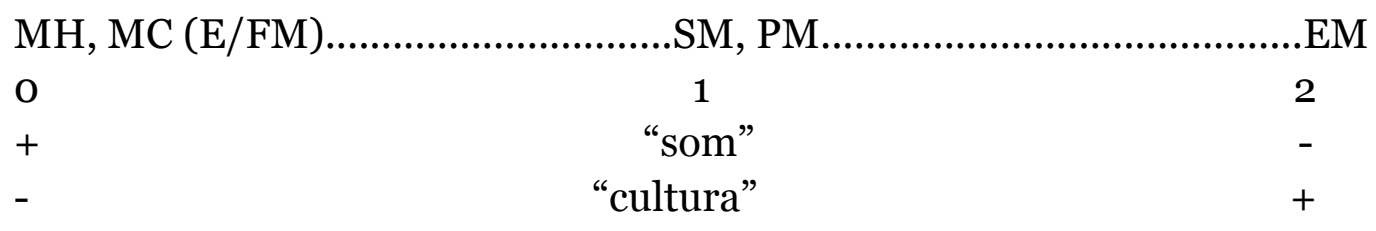

No ponto zero da escala, estão as duas "musicologias musicais", provindas do círculo artístico correspondente: Musicologias Histórica (MH) e Comparada (MC) [futura Etnomusicologia (E)]. Elas são as que mais enfatizam a "análise sonora". Incluo o Folclore Musical (FM) na Etnomusicologia. No final do contínuo, a "musicologia filosófica" (Estética Musical - EM). Intermediando os extremos, as "musicologias humanas": Sociologia e Psicologia da Música (SM e PM).

Conforme trabalharei na terceira parte deste escrito, o par de categorias "som"/"cultura" congrui com os de "sensibilidade"/"inteligibilidade" e "outros"/"nós"(respectivamente seus termos), o que evoca o platonismo da Alegoria da Caverna e do Esquema da Linha Dividida. 
O universo das musicologias - uma diáspora - não é nem monolítico nem isonômico, tratando-se de um espaço epistêmico descontínuo e enrugado ${ }^{19}$.

A maioria das análises sobre as relações mantidas pela Etnomusicolo- gia com as outras musicologias tende a privilegiar seus nexos com um discurso disciplinar que pretensamente seria a Musicologia Histórica.

Simultaneamente, tais investigações inclinam-se por construir uma identidade etnomusicológica com base na suposição do contraste que existi-ria entre os dois campos do ponto de vista da ênfase no enfoque do contexto. A Etnomusicologia seria aqui a rainha da contextualização - medida de sua conterraneidade "antropológica" -, aquela pretensa Musicologia Histórica (injustificadamente aliás) sendo vista como inapetente na direção da abordagem das interfaces contextuais, emblema de sua atribuída alteridade "histórica".

Para tais análises, o segundo campo torna-se a Musicologia por excelência e a Etnomusicologia sua única resposta do continente Ciências Humanas. Quase nada há aqui de referência às outras musicologias.

Tal tendência analítica espraia-se pela literatura etnomusicológica, desde seus manuais e compêndios - via de regra, nas introduções destes, quando se elabora a história da disciplina - até suas obras menos normais (Kuhn, 1975). Este perfil diz respeito aos anos 50-6o - aqui, meu objeto de atenção -, sendo de notar, porém, que a tendência pode ser vista como projetando-se adiante e aquém daí. Isto, mesmo em contribuições como as de C. Seeger (1977) e Chase (1976), excepcionais em outro sentido ${ }^{20}$.

A predominância dessa inclinação analítica somada à ausência de estudos que reportem as relações da Etnomusicologia com as outras musicologias apontam para uma profunda encarnação histórico-cultural-social da maneira de a disciplina construir seu quadro articulatório com as áreas inclusivas da Música e da Antropologia.

O que este mito de origens procura remarcar é que a elaboração da Etnomusicologia continuamente se faz de dentro da Música - nas suas margens musicológicas -, como uma segmentação a partir de uma ancestral unidade com uma Musicologia Histórica genérica. Isto, no sentido de uma migração para o território antropológico - nos seus confins de artisticidade: das margens quase inteligentes da Arte, onde se busca as origens da Música Ocidental na música dos "outros", para os limites quase sensíveis da Ciência (Social) - local de procura de ilustrações e exemplos não-verbais da alteridade máxima.

Embora com essa ótica se tenha elaborado uma produção útil no senti- do de uma história natural, descritivo-cronológica, dos nexos da Etnomusicologia com a Música e com sua posterior tematização "humana" através da Antropologia, o quadro daí resultante - o de um mito de origens sob linguagem histórica - é incompleto e confuso. Incompleto porque deixa de dar conta das

19 Servi-me das seguintes fontes no sentido do presente quadro das musicologias: Harrison (1963), Ward, ed. (1975), Hindley, ed. (1977), Hameline (1978), Etzkorn, ed. (1973), Shepherd et atii (1977), Me nezes Bastos, F. (1987), Rowell (1987) e Albersheim (1973). Os textos etnomusicológicos estão assinalados no decorrer da parle dois.

${ }^{20}$ A primeira, por postular a própria "juntura musico lógica". A segunda, flagrantemente inspirada em Lévi-Strauss (1970), por discriminar a Etnomusicologia da pretensa Musicologia Histórica em termos não temáticos, mas teóricometodológicos e epistemológicos. Ambas as obras, no entanto, generalizam esta Musicologia Histórica, constituindo-a como alter privilegiado da Etnomusicologia. 
várias outras musicologias e, sobretudo, do sistema de relações entre todas elas. Confuso pois generaliza a Musicologia Histórica como a Musicologia, deixando de reconhecer que as disciplinas musicológicas- exceção feita à Estética Musical - nascem no plural, simultaneamente no século XIX, inclusive a Musicologia Histórica. Esta não tem, assim, nenhuma anterioridade sobre as demais, a não ser que se cometa o equívoco - base, enfim, da tendência em análise - de confundi-Ia com os discursos antecessores de todas as musicologias: a História da Música e a Teoria Musical.

Conforme já estudado, foi através de uma ruptura nesse discurso conjunto (História da Música/Teoria Musical) que nasceram, a meios do século XIX, as "musicologias musicais" (as "humanas", por tematização homônima também desse discurso). O objeto de ambas as disciplinas "musicais" - usando categoria nativa - é a música do passado. No caso da Musicologia Histórica- e através da partitura -, o passado aí coloca-se dentro da moldura da Música Ocidental. Quanto à Etnomusicologia (então, Musicologia Comparada), este passado são as "músicas exóticas", supostas na origem da Ocidental, músicas estas logo abordadas através da fonografia. Respectivamente, músicas do "nós" e do "outro". A primeira sempre pensada como ex-pressão - quase sempre dolorosa, pois premida - de indivíduos, grandes indivíduos ("mestres", "nomes", "gênios"). A segunda, como manifestação de "sociedades", "culturas". Quer dizer, música, de um lado, como liberdade, de outro, como prisão.

As Musicologias Histórica e Comparada (Etnomusicologia) não são, pois de acordo com a genealogia do mito -, mãe e filha. Elas são irmãs. Seu nascimento - como intentei mostrar - é o resultado de uma ruptura nos discursos da Teoria Musical e da História da Música, ruptura esta feita na direção da construção de algo novo no ouvir Ocidental - a música do passado -, tentativamente de acordo com o mensageiro e não com o intérprete.

Pretendendo estudar as relações da Etnomusicologia com as suas homólogas, inicialmente levantei um quadro exploratório que me permitisse melhor imaginar para onde aponto quando digo musicologias. Verifiquei em seguida que os estudos relacionais da disciplina com as congêneres privilegiam sua vizinhança com uma pretensa Musicologia Histórica, na realidade com a História da Música/Teoria Musical.

Conforme levantei, a Sociologia da Música não é uma "musicologia musical" mas "humana". Por outro lado, ela é uma Ciência Social, o que não é o caso da também "humana" Psicologia da Música. Dessa maneira, a Sociologia da Música tem tudo a marcá-la como uma oposta da Etnomusicologia, sendo de notar que o aguçamento do intercâmbio entre ambas a partir dos anos 70 está na base da perspectiva de um projetado campo musicológico a que chamei de "estudos musicais". Decido-me assim a estudá-Ia agora, comparativamente com a sua prima cruzada, a Etnomusicologia.

Para uma Antropologia da Sociologia da Música 
Embora as origens da Sociologia da Música possam ser remontadas a Comte (1798-1857), Dilthey (1833- 1911) e Simmel (1858-1919), ela só se constitui como subcampo da disciplina mãe em 1921, com o célebre Die rationalen und sociologischen Grundlagen der Musik (Weber 1944)21.

Exibindo uma erudição notável com relação à literatura musicológica da época, erudição esta que o faz viajar do Ocidente à China e à Índia, aos índios norte-americanos e aos camponeses europeus, Weber constrói nesse texto uma abrangente teoria da Música Ocidental, fundada na perspectiva da racionalidade. Esta racionalidade deve ser entendida nos termos da efetiva eficácia teleológica do sujeito sobre o material sonoro da música, tal material definindo-se como um conjunto de fenômenos acústicos em torno da série harmônica. Não há no material sonoro da música de Weber nada além de uma pura manifestação do mundo físico-acústico. Ele não tem escopo semiológico, o que só irá acontecer quando de sua apropriação social, a questão contextual aqui sendo determinante.

Para Weber, assim, de um lado o material sonoro da música, vazio de significado; de outro, sua interface contextual, sua efetiva realização social como música propriamente dita. Intermediando estes dois termos - uma transformação do som e cultura etnomusicológicos -, a razão teleológica. (Há nesse esquema conceitual weberiano um grande paradoxo: como distinguir este material sonoro da música de qualquer outro material sonoro senão pela musicalidade? Musicalidade esta mais essencial do que aquela de sua própria música na medida em que o concreto pensado está mais próximo do real do que o concreto figurado?)

O estudo da música, pois, para Weber também se constitui dilematicamente e de forma mais vigorosa que a etnomusicológica: enquanto que na Musicologia Comparada (depois, Etnomusicologia), o som merece uma abordagem já musicológica - daí se evidenciando a Musicologia Sistemática -, na Sociologia da Música weberiana ele é um objeto acústico, enfoca- do como um universo específico da teoria ondulatória do som, do qual ele exclui o mundo dos ruídos.

É através dessa domesticação racional do som que Weber irá divisar a contrastação da Música Ocidental com as músicas de todos os outros povos. Transfiro a palavra para ele:

O mesmo ocorre com a Arte. O ouvido musical era, aparentemente, até mais desenvolvido em outros povos do que atualmente entre nós: certamente não o era menos [...] Mas a música racional - tanto o contraponto como a harmonia -, a formação da sonoridade na base de três tríades com o terceiro harmónio; [...] só existiram no Ocidente [...] [1985: 2]

Aqui, Weber aprisiona a música na estreiteza. Inicialmente, ao separar de maneira irreversível a racionalidade do ouvido musical, reificando-os nos termos do binômio - respectivamente os termos - "nós"/"outros". Em seguida, ao legitimar etnocentricamente uma visão evolucionista pobre das relações entre os diversos sistemas musicais humanos. O que será para Weber este 
ouvido musical senão aquele que, não sendo teórico, tão somente é estésico e mágico (dos "outros")? Mas tem mais: Weber, por fim, não alcança discriminar nessa racionalidade - o que seja produção discursiva valorativo-ideológica. Assim, ele acaba por proceder quanto à Música Ocidental como o observador incauto do Ocidente que confunde o valor da igualdade com o igualitarismo mesmo.

O que se tem aí à frente do espelho senão o duplo do dilema etnomusicológico, que lá atrás aparecerá invertido e refratado (pois numa reflexão que não produz o idêntico mas o "outro")? De um lado, o material sonoro e o social; de outro, o som e a cultura. Note-se como ambos os binômios se desenham: seus primeiros termos - que apontam o plano de expressão da música - não passam de projeções inertes dos segundos - referentes ao contexto -, inviabilizado, por outro lado, o sentido.

A inversão retratada, entretanto, só se vai configurar plenamente quando da transformação do primeiro binômio (aquele que se refere à Música Ocidental) no segundo (à dos "outros"). Esta transformação se faz pelo salto da racionalidade e do indivíduo à estesia e ao gregarismo. Nas fundações, pois, da Sociologia da Música o que se pode levantar é que o dilema etnomusicológico, sobre ser o cerne da Etnomusicologia, não passa de uma manifestação regional de algo muito mais abrangente: o paradoxo musicológico, âmago do pensar Ocidental sobre a música.

A partir de Max Weber, a Sociologia da Música se desenvolve, alcançando sedimentação nos anos 50. Nesta época, aparecem os primeiros manuais e compêndios do campo, sendo de notar que na direção desta sedimentação a produção européia parece ter muito maior impacto que a norte-americana.

Neste processo, ocorre com a Sociologia da Música, do ponto de vista das relações de identidade do campo científico correspondente, o inverso que se deu com a Etnomusicologia: se esta, provindo da Música, foi buscar legitimidade "cultural" (inteligibilidade) na Antropologia - oferecendo-lhe em troco ilustração musical (sensibilidade) -, a Sociologia da Música, nascendo da Sociologia, direcionou-se para a Música, na demanda de legitimidade "musical".

Assim é que, começando pelos anos 50, os textos de Sociologia da Música vão ganhando cada vez mais "musicalidade" - às custas de um número paulatinamente mais profuso de "exemplos musicais" -, deslocando-se, desta maneira, sua por assim dizer "verbalidade" inicial.

Finalmente, verifique-se que este movimento de maturação da disciplina vai também se caracterizar por uma grande expansão temática, desencasulando -se a Sociologia da Música da Música Ocidental. Vive-se agora a cultura de massa - ou a indústria cultural (conforme Adorno; vide adiante). A música, aqui, virtualmente invade o planeta. Não - é certo - a música, mas aquela, categorizada como música popular, que denominei de terceiro kathólon (universal) do Ocidente, elaborada com centro no estabelecimento tecnológico- 
industrial. Neste novo Gregoriano, a catolização estética do Capitalismo, coexistente com a sua ética, protestante ${ }^{22}$.

A Sociologia da Música que se faz a partir dos anos 60, depois dos deslocamentos produzidos pela Segunda Guerra, se elabora sob o impacto da obra de Adorno (1903- 1969), cuja contribuição, muito embora remonte aos anos 30, só alcança a merecida projeção a partir de então.

O fato de Adorno ter sido um talentoso músico, discípulo de Alban Berg e, assim, "neto" de Schoenberg - o criador do dodecafonismo -, é de absoluta relevância no sentido de uma adequada compreensão de sua obra. Isto, por dois motivos. Inicialmente - o mais óbvio -, porque sua produção sociológica se faz visceralmentemente de dentro da música, tomada, não, como um "particular" ou "específico" - minimização a que o pensamento oficial sempre procurou reduzir a música no Ocidente - mas, numa tradição que remonta pelo menos a Spengler e Hegel (para não dizer que ela tem início em Aristóteles) como um dos "gerais" por excelência disto a que se pode chamar de Ocidente. Mas há outro motivo menos óbvio aqui: Adorno, como compositor, se filia à variante bergiana (oposta à weberniana) da estética dodecafônica.

Leibowitz (1957) elabora uma fascinante teoria sobre a Música Ocidental, reconhecendo o cromatismo como o motor de sua história. Para Leibowitz, o que acontece nesta história - desde o século VI com o Gregoriano até o dodecafonismo - é uma luta de foice no escuro entre o diatonismo e o cromatismo, entre a planura do primeiro e o enrugamento do segundo.

Sabe-se muito bem como os teóricos medievais e renascentistas católicos intentaram aprisionar o cromatismo na planura diatônica, convencidos que estavam da dissolução ética que o primeiro provocava: lassidão, lascívia e tantos outros diabos mais.

Com a "profanização" da Música Ocidental - ou a "catolização" da música da Europa não católica -, este projeto cromático toma cada vez mais corpo, o que - é certo - sempre se deu sob a disciplina diatônica.

O Romantismo é que parece - sempre segundo Leibowitz - ter provocado o começo do fim do éthos diatônico, o que é radicalizado pelo expressionismo wagneriano e rompido por Schoenberg. Para o autor em comentário, a Música Ocidental, a seguir a mesma racionalidade com que irrompera com o Gregoriano, chegara aí - com Schoenberg - ao fim. Isto, sob pena de anacronismo ou caos, absurdos dentro de sua lógica (vide a terceira parte deste escrito).

Esta teoria da Música Ocidental não é simplesmente de Leibowitz, mas o pano de fundo da cultura estética dodecafônica, alcançando - sobretudo em sua segunda geração (a de Alban Berg e Anton Webern) - o estatuto de manifesto

\footnotetext{
${ }_{22}$ Entre os primeiros e mais importantes manuais da Sociologia da Música, vide Blaukopf (1951). Conforme Etzkorn (1973: 8), Blaukopf compendia neste livro que o primeiro objetivo da disciplina seria "conceber a produção e a reprodução da música dentro do contexto do processo histórico e 'evolutivo' da sociedade humana". Em outra parte, do manual o autor assevera, porém, que na Sociologia da Música a Sociologia e secundária para a Musicologia. Esta afirmação parece contrariar sua definição da disciplina, claramente pouco "musicológica". Note-se nesta, por outro lado, a abrangência que concede ao campo, que passa a abarcar toda e qualquer música e não somente a Ocidental; e a cristalização de uma pulsação dilemática Sociologia/Música, que, como visto, não e original nesta "musicologia humana".
} 
apocalíptico: chegara ao fim a Música Ocidental! Na terceira geração e adiante, dentro sempre deste movimento de "vanguarda", os nativos não tinham mais dúvidas quanto a esta morte expressionista, a morte do próprio Ocidente através da música"23.

A análise da obra de Adorno revela de imediato uma postura crítica amarga contra toda música que não a Grande Música do Ocidente. Leia-se: contra as linhagens da Música Ocidental que não tinham como télos o dodecafonismo. Seu célebre ensaio Filosofia da Nova Música (1974), que claramente contrapõe Schoenberg a Stravinsky - ali respectivamente o Progresso e a Restauração -, é programático a este respeito. Mas não é somente aí que isto se mostra. Seus estudos sobre a música popular (tipicamente 1983b) trazem uma condenação irremovível a ela: depravação e epigonismo, ao que adiciona uma alienação congénita, responsável pela outrificação do lazer na preparação para o trabalho. Desta maneira, para Adorno (1986) a cultura de massa não é uma cultura, mas uma indústria. Isto equivale a dizer - no contexto de sua forma de pensar - que o homem aqui deixa de ser ativo, tornando-se impotente.

É difícil ler Adorno sem lhe revelar esse amargor e essa impotência perante não só o objeto de seu estudo e deleite - a música - mas também, implicitamente, a sua própria teoria crítica. Aqui, a racionalidade também comparece como senha reificada - senha para a civilização -, com relação ao que ele é franca mente weberiano quanto à Música Ocidental. Isto o conduz a abordar a música na estritura de uma acusmática parcial, que vai eleger tão somente os níveis melódico e harmônico como aqueles por excelência da musicalidade Ocidental. Desta forma, o ritmo - como também o timbre - não passa de um migrante ilegal em seu Ocidente, imigrante bárbaro ou selvagem (muito daí - como impensado, eu sugiro - nascendo a condenação a Stravinsky e ao jazz). Consistentemente, Adorno legitima, científica e ético-politicamente, tão somente uma corrente estética da Música Ocidental, estacionando ademais na posição de que, enfim, a história sempre esteve pronta, reinversão do Marx que invertera Hegel24.

Quando Adorno, no entanto, se liberta da prisão hipercrítica, ele atinge uma fina síntese teórica na direção da integralização da música como linguagem. Aqui a sua ruptura efetivamente criadora:

O conceito essencial de sociedade, entretanto, que não só abarca todas as áreas parciais, mas comparece por inteiro em cada uma delas, não é um mero campo de fatos mais ou menos interligados, nem é uma classe lógica suprema, à qual se pudesse chegar pela progressiva generalização. Ele é em si mesmo um processo, um nexo que se produz e produz os seus momentos parciais, uma totalidade no sentido de Hegel [1983a: 1991].

\footnotetext{
${ }_{23}$ Permito-me confidenciar ao leitor que eu mesmo, nunca como numa "Robinsonada", vivenciei este clima de morte da Música Ocidental. Isto, como estudante de Composição Musical na Universidade de Brasília nos anos 6o. Devo acrescentar, entretanto, que, aluno de Levi Damiano Cozzella, de Rogério e Régis Duprat e de Cláudio Santoro, minha genealogia era ali muito mais weberniana que na linhagem de Alban Berg. Isto, se me fez abandonar a música erudita pois "tudo já estava feito" -, me permitiu abraçar a música popular e a Antropologia.

${ }_{24}$ Para uma crítica marxista ao marxismo adorniano, vide Boehmer (1972), texto do qual muito me aproveitei na presente leitura, juntamente com Charles et alii (1972), Arames (1983) e Cohn (1986). Contrariamente a Berg, Webern detém um pensamento estético mais fértil na direção de uma superação da morte expressionista da Música Ocidental, através do serialismo (Webern, 1984). Por outro lado, lembre-se como a postura de Adorno sobre a indústria cultural se contrapõe à do também "crítico" Benjamin (1983). Isto antecipa os debates sobre o "compro misso político" da Ane. Sobre estes e para o caso da MPB, vide Menezes Bastos $(1977,1982)$.
} 
Este trecho seminal de Adorno - do mesmo escrito onde ele define a Sociologia da Música como uma "das diversas sociologias-de-alguma-coisa" (vide supra) - rompe com as perspectivas particularistas da música com relação à sociedade (e à cultura). Aqui está a ruptura do paradoxo musicológico, implicitamente um começo de viabilização de uma Semântica Musical.

A teoria da música de Shepherd (Shepherd et alii, 1977) parte de uma crítica radical ao pensamento Ocidental sobre esta linguagem. Sintomático desta crítica é o exame a que ela procede das obras de Langer (1960) e Meyer (1967), pensadores que, discutindo a problemática do significado musical, concluem que ele se instala na emocionalidade e na subjetividade.

Alternativamente, o que Shepherd propõe é o enfoque da questão em termos "êmicos". De início, pois, esfumaça-se aqui a abordagem da música como "linguagem universal", fora da Torre de Babel.

Lembrando o Mauss de $A$ Prece (vide supra), Shepherd recoloca a questão do significado em música nos termos de uma codificação social onde o plano de expressão da linguagem aparece como um código concreto produzido socialmente, ao nível seja da emissão (produção), seja da recepção (consumo). Aqui, neste deslocamento tão profícuo, os ecos arquetípicos do projeto de Adler.

Os caminhos da Sociologia da Música parecem constituir uma inversão transformada daqueles da Etnomusicologia. Apesar de se constituírem em cima de categorias de entendimento basicamente sinônimas, as duas musicologias relacionam-se com as Ciências Sociais respectivas de forma cruzada. A primeira, originalmente de dentro da Sociologia como uma sociologia típica, pouco a pouco se direciona para o território da Música, em busca de substância musicalartística. A Etnomusicologia, cria da Música, procurará, por outro lado, legitimidade "cultural" na Antropologia.

Na Sociologia da Música, o objeto música se erige nos termos do indivíduo e da racionalidade (uma forma de inteligibilidade). Isto, apesar da hierarquia quero dizer, do holismo - presente no sistema da Música Ocidental - de início, seu objeto exclusivo - e da ideologia da sensibilidade aí constante, inversão que configura o salto da "religião da arte" (conforme Spengler; vide adiante) até a sua Ciência.

Quanto à Musicologia Comparada, uma outra inversão: a música é divisada aí a partir dos prismas do coletivo e da irracionalidade, respectivamente do cultural (sob a redução do étnico) e de uma quase animalidade. Em ambos os campos a análise contextuai é dominante, abandonada a problemática do sentido. Termo a termo, paradoxo musicológico quanto ao "nós" e ao "outro". O crescimento do mercado fonográfico, a invasão do planeta até suas franjas mais remotas pela música popular, novo kathólon, transfiguram a musicalidade Ocidental: a Música Ocidental é agora, ela mesma e toda ela, música do passado. As questões da etnicidade e do "compromisso político" da música são cruciais nesta direção: o novo kathólon é suficientemente "universal" para incluir desde o Flamenco às Raga, desde o Baião ao Bebop, o Jazz sendo agora a música que tudo canibaliza. 


\section{Sobre a construção do Ocidente pela Música Ocidental e sobre o papel aí das "musicologias"}

O sistema sócio-cultural a que se chama de Música Ocidental ("Grande Música", "Música dos Mestres", "Música Clássica" ou "Erudita") constitui- se num dos mais definitivos horizontes da Civilização correspondente. Sob um determinado ponto de vista que buscarei evidenciar, ele é muito mais que isto, sendo quase soberano.

Muito embora o sistema em toque tenha significação em muitos universos de conhecimento - no da História das Ideias, por exemplo -, ele é especificamente pertinente aos discursos da História e da Teoria Musicais. Estes discursos- antecessores das musicologias -, muito longe de serem extintos na Civilização que se imagina como aquela por excelência da história e do progresso, aí têm plena existência vivida, através de instituições como os conservatórios - que os conservam - e de rituais como os concertos, que os reinventam constantemente. Aqui, a Música Ocidental encontra seus templos ideais de sacralização, cultivo e consensualização, templos estes que estranham qualquer espaço-temporalidade exterior e onde a música do passado tem vigência antes mito-cosmológica que cronológica.

Longe de querer reificar, por essencialidade cultural, esse poder altamente definitivo da Música Ocidental - o que tem sido, aliás, a tônica de sua abordagem dentro do território da História das Ideias -, minha posição neste texto será por excelência "sociológica". Isto significa dizer que tal privilégio dessa Música - o outro lado da moeda cujo primeiro estampasse o paradoxo musicológico - deve ser visto como algo socialmente construí- do, num contexto de múltiplas construções sociais. É desta maneira "sociológica" que pretendo mostrar como a Música em análise é a instância primordial de imaginação de um determinado tipo de ocidentalidade: aquela que exclui todas as "outras culturas" - inclusive a antiguidade Greco- Romana- e instala a Europa como o concerto das nações.

Os critérios de construção da Música Ocidental são muitos e variados, combinadamente estendendo-se desde os de ordem puramente acústicomatemática - lembre-se Weber - até os de feição estético-filosófica, passando pelos de caracterização mais psicológica e sócio-cultural. Os compêndios de História da Música - assim como, em escala menor, os de Teoria Musical - são férteis na administração rotineira dessa criteriologia.

Seja qual seja, porém, a combinação de espécies de critérios adotada pelos muitos tipos de exegeses na direção da elaboração do sistema em estudo, todas elas - e, aí, uma generalidade de sua forma nativa de construção - são unânimes na afirmação da distintividade especial da Música Ocidental com relação às 
"músicas exóticas", sejam estas "primitivas" ou "orientais" (de "altas culturas") ou, mesmo, Ocidentais da antiguidade clássica 25.

É certo que a grande maioria dos compêndios de história da Música Ocidental trazem, sintomaticamente em apresentações introdutórias, estudos mais ou menos circunstanciados sobre as "músicas exóticas". Mas assim o que fazem, recontando um mito de origens, é produzir a Música Ocidental por contraste com um passado impresentificável.

A temporalidade dos começos da Música Ocidental é a Idade Média. Nesta, os séculos VI (com o Gregoriano), IX (polifonia), XII: (formalização da notação mensurada) e XIV-XV (Ars Nova) constituem os momentos preferenciais para o estabelecimento inicial do sistema. Isto, porém, é dissensual, variando a opção cronológica de exegese para exegese. Tal dissenso - sob o consenso, no entanto, de que essa Música se instala sob o império da leitura e da escrita - aponta para o fato de que aqui os tempos histórico e mítico se confundem na "noite" medieval.

Escolho Através da Música (Brum, 1897) para dar começo à minha reflexão. Minha escolha não é casual, já com ela querendo apontar para dois fatos salientes em minha argumentação: a Ocidentalidade de que aqui estou a tratar não se estabelece estritamente em termos geográficos europeus. Pelo contrário, sua cartografia, como sua ideologia, é universalista. Mas há mais: essa Ocidentalidade tentacular não é o objeto da elaboração apenas de intelectuais do Primeiro Mundo. A obra que agora será meu objeto de atenção foi escrita nos fins dos séculos XIX no Rio Grande do Sul, por um musicólogo gaúcho ${ }^{26}$. Passo a ele a palavra:

Embora ella [a música] haja sido distribuida á todos os povos do Globo com mais ou menos profusão; embora guarde proporções physiologicas com as disposições naturaes de cada um, comtudo, só apresenta-se-nos como aquisição monumental quando tratada pela arte creada pelo progrésso [Brum, 1897: I].

Monumentalidade e progresso. Estes, para o autor, são os traços básicos da Música Ocidental com relação às dos "outros". Com monumental, o que Brum procura enfatizar parece ser a complexidade que a música atingiu no Ocidente. Mas por que será monumental o nível desta complexidade? Note-se que as músicas dos "outros" para ele não são monumentais, por serem produções exclusivamente physiologicas e naturaes. Somente quando "tratada pela arte creada pelo progrésso" é que a música, para Brum, é uma aquisição monumental. Somente, assim, quando elaborada pela arte (téchne, no sentido estrito de "técnica") que o progrésso tomou possível é que a música resulta digna de ser lembrada (afinal, "monumento" não é aquilo que aponta a lembrança de algo digno de ser recordado?).

25 Também as músicas "folclóricas" e "populares" aqui são objeto de contraste, numa linha porém de obviação: as nãoOcidentais já pela sua geografia alienígena; as geograficamente Ocidentais. por outro lado, em função de sua Ocidentalidade apenas local-regional, no máximo nacional. Isto, nas exegeses contrastivas, se confunde com as marcas da paroquialidade e da falta de cultivo técnico. Neste mesmo quadro, o anacronismo é predicado as "folclóricas" (sobrevivências), enquanto que a mercabilidades e atribui às "populares". Para um tratamento relativo ao caso brasileiro dessas questões - quanto ao contras te MPB/"Música Erudita" -, vide Beato (s.d.).

${ }_{26}$ Para referências a Marciano Brum, vide Corrêa de Azevedo (1952: 88). Para a questão do cultivo da Música Ocidental no Brasil, vide Beato (s.d.), Lucas (1980), Menezes Bastos (1977, 1982, 1986b) e Trajano (1984). 
O que será para Brum esse progrésso senão, ao mesmo tempo, causa e efeito do exercício daquela inteligibilidade a que Weber carismaticamente chama de racionalidade e que Brum parece rotinizar? De um lado, o profissional magnífico, "europeu", de outro, o quase diletante da "América do Sul" (ou "Latina") o que fazem - produzem e reproduzem - senão ressoar a ideologia de que a Música Ocidental - oposta a todas as "outras" - é aquela que está submetida à disciplina e ao controle da inteligência, com o que se objetiva livrála da estesia?

Carpeaux (1977) - tudo menos um diletante - é mais radical ainda no esforço da construção da Música Ocidental como algo absolutamente distinto de tudo o mais o que possa vir a ser música. Assim delimita ele seu objeto de estudo; em termos

\begin{abstract}
da música ocidental: isto é, da música européia [...] Não trata [este livro], porém, da música de outras civilizações, seja da árabe, da indiana ou da chinesa. O autor do presente livro está convencido que a música, assim como a entendemos, é um fenômeno específico da civilização do Ocidente [...] Em nenhuma outra civilização ocupa um compositor a posição central de Beethoven na história da nossa civilização; nenhuma outra civilização produziu fenômeno comparável à polifonia de Bach [1977: 9].
\end{abstract}

Monumentalidade e progresso? Certamente. Mas também seus emblemas mais caros: grandes indivíduos e um profundíssimo nós (oposto a todos os "outros"), pan-europeu, escancaradamente claro. Mas não fica aí o sábio em seu esforço. Logo adiante, ele assevera:

o leitor não encontrará, neste livro, o costumeiro capítulo introdutório sobre a música dos gregos e romanos. A música da Antiguidade não exerceu sobre a nossa a mesma influência da literatura, das artes plásticas e da filosofia gregas. Poucos são os fragmentos dela que subsistem; e não sabemos lê-los com segurança [9].

Para a Música Ocidental, pois - espantosamente somente para ela dentre todas as outras Artes -, os Antigos são "outros", deles só se conhecendo fiapos dificilmente inteligíveis: "do que os olhos não vêm, o coração não padece", provérbio máximo, talvez, do imaginário de historicidade da Música Ocidental, música esta que aqui se estabelece, pois, como uma Arte de leitura e escrita, posta entre parênteses a eficácia de sua oralidade, no sentido do deslocamento do "milagre grego" pelo "milagre europeu". Carpeaux (:9) toma o século XIV (com a Ars Antiqua) como marco inicial da Música Ocidental, apontando para a acumulação primitiva de capital e para o aparecimento do trabalhador livre logo no século seguinte - como fatos fundamentais na direção da consolidação dessa erupção musical ${ }^{27}$.

A Música Ocidental, dessa forma, sobre ser uma Arte que retira a sua monumentalidade do fato de ser submissa à disciplina da inteligência particularmente através da leitura-escrita -, é $a$ Arte que por excelência define a Europa como o concerto das nações, um sistema social espetacular - para o mundo; sua plateia -, constituído pela pulsação entre o Iodo e as partes. Aí, os contornos de sua universalidade, catolicidade. Estranha forma, esta, de "nos"

27 Permito-me lembrar que, por motivos diferentes - sob a chave de leitura da degenerescência expressiva -, também Rousseau (1978: 196-198) vê uma separação abrupta entre as músicas da antiguidade clássica e européia. Autores como Leuchter (t946) e Leibowitz (1957), por outro lado, ao "recuarem" os inícios da Música Ocidental até o Gregoriano, no século VI, apontam para uma ligação congénita sua com a tradição clássica (greco-hebraica). 
pensarmos: um concerto de nações por oposição aos "outros" - bandos, tribos, clãs, fratrias etc.; gregários ${ }^{28}$.

Hegel, em sua Estética (1974: 177 ss.) - que, quanto à música, está em franca dissonância com o Kant da Crítica do Juízo (Kant 1961) ${ }^{29}$-, formaliza as bases filosóficas modernas desse tipo de visão da música que a posição de Carpeaux ilustra. Para Hegel, esta Arte, graças a ser sonoro - auditiva e assim estar despegada - segundo o filósofo - de toda exterioridade, tem como "missão principal [...] não, reproduzir objetos reais, mas [...] fazer ressoar o eu mais intimo, a sua mais profunda subjetividade, a sua alma ideal" (1974: 182).

Nesta passagem de Hegel, numa só caixa, três pontos da maior relevância na direção de minha argumentação: a axionomia dos canais senso- riais, que erige a visão em valor máximo quanto à fidedignidade sensória e que desloca a audição para a subjetividade (Menezes Bastos 1973); a des-semantização - dessocialização - da música; e, finalmente, um entendimento dir-se-ia "naturalista" da mimese artística ${ }^{30}$.

A Música Ocidental, pois, é um sistema imaginado, e por exegetas tão díspares entre si quanto os agora enfocados - sintoma de que esta imaginação não é isotópica do ponto de vista sócio-cultural -, como a música diacrítica da ocidentalidade. Seus caracteres básicos são: monumentalidade e progresso; e interioridade e universalidade.

O primeiro par de categorias aponta para o seu éthos disciplinado, que resulta da submissão de sua ordem material-sensível (sonoro-auditiva) ao controle da inteligibilidade. Esta inteligibilidade é algo de procurado explicitamente, acenando para uma sociabilidade construída e trabalhada. Esta não é uma sociabilidade animal-humana original, a música aí sendo uma téchne na acepção de "artesanato habilidoso". Este par distintivo aplica-se particularmente às relações de contraste da Música Ocidental com uma genérica "música dos 'outros", "exóticas" ("primitivas" ou "orientais") ou, mesmo, "populares" ou "folclóricas ". Quanto à música da Antiguidade, sua falta de permanência documental escrita é levantada como critério de oposição.

O segundo par contrastivo (interioridade e universalidade), montando-se sobre o primeiro, dá conta da pertinência pan-européia da Música Ocidental: trata-se de uma música de "grandes indivíduos" (nomes, mestres), membros de um sistema nacional-internacional ("civilizado"). Vale desdobrar este ponto. Primeira dobra: a universalidade da música de que aqui trato esgota-se nas franjas do sistema político europeu. Este sistema é aberto e movente na medida em que quem (nação) queira nele ingressar - participar de seu concerto obtenha as condições internas necessárias ao consenso externo. Segunda dobra:

\footnotetext{
28 Recordo que a forma concerto - a partir do século XVII - supõe um "acordo" (concerto) entre um ou mais instrumentos solistas (solo) - metáfora do indivíduo - e a orquestra (tutti) - da sociedade. Este "acordo" registra tanto o contraste e a alternância quanto a complementariedade e a simultaneidade. A forma pode ser remontada ao século XVI (com o concerto eclesiástico), quando a pulsação vai se colocar entre o canto e o acompanhamento instrumental.

${ }_{29} \mathrm{Na}$ Crítica, Kant (1961: 165- (8 1) reduz a música a um puro jogo de sensações sem conceitos, classificando-a nas hierarquias mais baixas do sistema das Belas Artes (Menezes Bastos, F. 1987: 133).

30 Lembro que Hegel, na mesma obra, divide as Artes em "clássicas", "românticas" e "simbólico- alusivas", do ponto de vista de suas compatibilidades com a "exterioridade" (natural e sociocultural) e "interioridade" (individual). Para Aristóteles, por outro lado, a imitação poética (leia-se artística) não se faz sobre aquilo que "aconteceu" - o que seria "fazer história" - mas sobre aquilo que "poderia ter acontecido " (segundo a verossimilhança e a necessidade). Vide Sousa (ed. 1966) para uma tradução e aná lise da Poética aristotélica.
} 
tal universalidade não elimina a validade nacional - até mesmo regional-local de cada uma das músicas de seu universo, percebidas aí, então, como variantes e, pois, aceitáveis: Músicas Flamenga, Italiana, Francesa, Alemã etc., Ocidentais. Daqui se excluem, é certo - conforme já anotei -, as músicas "populares" e "folclóricas"31.

Este segundo par contrastivo, por sua competência de constituir a paneuropeidade, ao mesmo tempo obvia e recusa o primeiro: a inteligibilidade agora é tomada, negligentemente, como tábula rasa a partir da qual se fará a música propriamente dita, enquanto criação. Fazer este, no entanto - agora -, não mais como o de uma téchne mas como o de uma poíesis. Aqui, sim, está o campo por excelência da Música Ocidental como Religião da Arte: na transformação da inteligibilidade primeira numa quase segunda natureza e, daí, na invenção da sensibilidadeda alma - fiel do culto ao belo enquanto sublime - e na recusa e renúncia à sociabilidade "deste mundo" - "Mein Reich is in der Luft".

Num primeiro movimento, pois, a Música Ocidental se constrói por contraste com relação a todos os outros "tipos" de música. Monumentalidade e progresso são, aqui, conquistas de uma inteligibilidade que retira a música do território do sensível, compreendido nos termos de uma sociabilidade natural, animal-humana. Com este movimento, trata esta música de definir a sociabilidade do Ocidente como algo trabalhado, muito diferente, pois, do gregarismo natural dos "outros" que decreta.

Seu segundo movimento, entretanto - não oposto, mas cumulativo do primeiro -, estabelece essa conquista inteligível como novo ponto de partida. Isto feito, transforma-a num supremo tipo de sensibilidade - não do coração, mas da alma -, o único que permite que, ao mesmo tempo, interioridade e universalidade se manifestem.

Jaeger (1965), contrariamente ao ideário Renascentista, reificado e legitimado pelo Iluminismo, evidencia que entre o mundo antigo e a Europa primitiva há uma profunda relação de continuidade. Lembre-se que para o Iluminismo a Idade Média é a "idade das trevas", espécie de noite mitocosmológica a intermediar a luminosidade do dia renascentista com o poente diga-se assim - do mundo clássico.

Para Jaeger, a chave dessa continuidade está dada pela paidéia (pedagogia). No caso, uma paidéia de Cristo, que ele vê fluir da própria paidéia grega clássica (1965: 24-25). Passa-se para ele, então, entre as formações sociais antiga e européia primitiva algo como uma inversão daquilo que Dumont (1985: 35-7 I) estabelece como nexo primordial entre os universos da alta e baixa Idade Média: uma politização da Igreja. Note-se que Adorno (1983b: 167) radicaliza essa visão, identificando neste processo eclesiástico de politização - cujo modelo de humanidade segundo ele é ático-espartano - um verdadeiro projeto de

${ }^{31}$ É instrutivo observar corno a este respeito Ocidentais e Xinguanos são parecidos, valorizando a universalidade e desqualificando a paroquialidade. Nada, desta maneira, estranho que em Eymakapúku (a aldeia dos índios Yawalapití, de fala Aruak) se faça o Yawarí, uma música (permita-se me assim sinalizar este ritual) Tupi-Trumai. Pois em Bonn não se pode levar a Aida, este ritual Latino (com licença para apontar para esta música como para um ritual)? 
engenharia social cuja base se encontra na república platônica, para ele, assim, muito mais do que um projeto simplesmente pensado.

Especialmente na República, Platão explicita seu pensamento políticopedagógico em termos da ascese (leia-se "exercício") que possibilita a ascensão do cidadão ao mundo luminoso da inteligibilidade e, assim, sua libertação das correntes que o prendem à ilusão do sensível. Observe-se que aí mesmo nesta obra, Platão - como, no futuro, o Kant da Crítica do Juízo - identifica a música com a sensibilidade bruta, concedendo primazia inteligível às artes da visão (da ideia, originalmente em grego) e da palavra (do conhecimento, também conforme originalmente em grego): na república platônica não se deve tolerar a música senão aquela que provoque a bravura dos soldados. Da mesma maneira, admitem-se aí as músicas cujos modos possibilite $m$ a adequada imitação da voz e da expressão do verdadeiro homem. A estética musical platônica, assim é, em tudo por tudo, uma ética e uma política intencionadas pela educação. Elas são construídas, por outro lado, sobre um diligente conhecimento semânticomusical pato-lógico ${ }^{32}$.

A sistematização que se conhece como Canto Gregoriano constitui uma das pontes fundamentais entre a Antiguidade e o cristianismo primitivo. Caracterizando-se, no plano teórico, como um desenvolvimento da músicopatologia clássica e helenística, no âmbito prático - leia-se litúrgico -, estabelece-se como o braço mais poderoso da paidéia de Cristo, medida de sua evidenciação como kathólon ("universal"). A iniciativa de elaboração do Gregoriano remonta ao labor de Santo Ambrósio (333 -397), o bispo de Milão que por primeiro introduziu hinos e salmos na Igreja Ocidental "para o povo se não acabrunhar com o tédio e tristeza" (Santo Agostinho, 1987: 156)33.

A consolidação, porém, de todo este trabalho músico-pedagógico só se dá no século VI, com a reforma gregoriana. Aqui, um novo tempo é imposto à Europa, tempo este calculado pelas artes do Canto. A partir daí, pode- se dizer que a história da gênese da Europa é a da exitosa expansão deste Cantus Planus (e não Figuratus), que invade e conquista para Roma (leia- se, para a Igreja) os bárbaros. O século IX, o da coroação de Carlos Magno pelo Papa Leão III limite, segundo Dumont (1985: 35-71), da politização da Igreja e da catolização do estado -, leva esta expansão às últimas consequências. Abrem-se, então, as portas para a polifonia e, depois, para a completa generalização da paidéia de Cristo em toda a Europa 34.

\footnotetext{
${ }^{2}$ No sentido de páthos ("paixão", "sentimento"; e também "doença") + lógos ("explicação", "conhecimento"). Como textos de acesso a Platão, vide Pessanha (1979), Adorno (l983b) e F. Menezes Bastos (1987). Vide Warmington \& Rouse (eds., 1956) para a edição da República consultada.

33 Uma postura culrural-essencialista quanto às origens da Música Ocidental no Gregoriano mostra-se, desde já, inadequada, pois os hinos e salmos referidos são "orientais" (quer dizer, originalmente judáicos e inicialmente adorados pela Igreja Bizantina). Vide Leuchter (1946).

34 As práticas politônicas, ao que tudo indica tradicionais nas músicas européias "exóticas" (isto é, não-cristãs), ingressam na Igreja em torno dos séculos IX-X. Isto, como resultado do processo de "popularização" que a música eclesiástica sofreu na direção de sua generalização pan-européia (Leuchter 1946). A colonização musical, portanto - e não somente com relação a este primeiro kathólon Ocidental -, encontra na "profanização" o ato supremo de seu canibalismo. Os casos de Portugal e Espanha - especialmente, do primeiro país - são exemplares a este respeito: a imposição do Gregoriano aí foi muito mais problemática, devido a resistências heréticas muito disseminadas, a cantos "católicos" locais - como o da liturgia hispano-gótica - e à impregnação da Península pela colonização árabe. Interessantemente, o cultivo da Música Ocidental nesses dois países, particularmente em Portugal, não se fez com a luminosidade característica que pôde encontrar na Itália, Alemanha e França. Em Portugal - dir-se-ia -, não há Grandes
} 
A linha de continuidade, assim, entre os dois mundos em consideração tem na músico-patologia e na sua correspondente prática litúrgica um de seus elementos chaves. No mundo antigo, a república - uma utopia - elabora a inteligibilidade sobre a música. A aplicabilidade, entretanto, deste conhecimento persiste aí como apenas um projeto. Já na Idade Média, com o Gregoriano, este conhecimento se avoluma ao tempo em que se institucionaliza como paidéia. A fundação da Schola Cantorum - ou sua reorganização, possivelmente pelo Papa Gregório nos finais do século VI ou começos do seguinte (Randel, ed., 1978) - é um sintoma dessa institucionalização, marca da aplicabilidade daquela inteligibilidade e, assim, da efetivação da utopia platônica. O salto, dessa maneira, que o Catolicismo representa na confluência Antiguidade-Europa Primitiva encontra substância fundamental na sua apropriação da música como linguagem integral. Uma linguagem portadora de um plano de conteúdo, além do de expressão, e especialmente adequada à colonização patológica. Essa apropriação, no entanto, é escamoteada e negada, recusada e renunciada, seja pelos oficiantes e teóricos, seja pelos fiéis.

A questão da representação que de si mesmos fazem os estados-nações ocidentais modernos vem merecendo, por parte de Dumont (1970, 1985), um tratamento paradigmático. Para este autor, os membros dessas sociedades se pensam como in-divíduos, quer dizer, "totalidades não-divisíveis". Indivíduos adicione-se - iguais entre si (cidadãos). Este pensamento sistematicamente se direciona no sentido de obscurecer e, mesmo, escamotear a submissão à ordem social inclusiva. Desta forma, os Ocidentais vêm o seu "estar no mundo" sob o prisma da liberdade. Note-se que essa ideologia, ainda segundo Dumont, se estabeleceu num processo de continuidade com a cristã primitiva, do indivíduo "fora do mundo ". Esta transformação se deu pela politização da Igreja, investida do papel de estado. Observe-se que esta chave de leitura do Ocidente reporta-se originalmente, por contras- te, ao esforço de Dumont (1970) de estudo do sistema de castas da Índia. Ali, o indivíduo empírico, ao contrário do que acontece no Ocidente, não se torna em valor - em totalidade livre e igual -, sendo visto como parte de um todo hierárquico (holístico) amplamente dominado pelas representações do puro (casto) e do impuro.

$\mathrm{Na}$ exposição precedente suponho ter deixado claro que a Música Ocidental, operando em dois movimentos cumulativos, produz, de um lado, a distinção "nós"/"outros ", de outro elaborando a ocidentalidade européia. No primeiro movimento, o contraste é desenhado sob a égide da inteligibilidade pura, comprometida com a definição do estado de humanidade em termos técnicos (de téchne). Já no segundo impulso, aquele que estabelece a individualidade e a pan-europeidade, a ordem circunscritora é obviada e a inteligibilidade é reelaborada como sensibilidade. Uma sensibilidade, entretanto, sublimada pela inteligência e que metaforicamente apontei como da alma, não do coração (a sensibilidade pura parece se estabelecer no sistema em estudo como a chave de um estado de humanidade que periga estar fora do

Nomes, como aliás tão agudamente revelam os compêndios de História da Música. Para a Espanha, vide Chase (1958) e Tello (1962). Para Portugal, vide Béhague (1986). 
controle político-social; leia-se, da inteligibilidade). Esta sensibilidade inteligível é que permite à Música Ocidental a refração hierárquica do indivíduo, transportando-o para o território de uma religião onde a criação (composição, interpretação) - imaginada como a de Deus, ex-nihilo - é o valor holístico integrador, medida da castidade com relação à música enquanto técnica. A música do concerto das nações, assim, põe e retira o seu homem do mundo, para usar expressões dumontinas. Aqui, o nexo mais original do paradoxo musicológico, na elipse que a Música Ocidental, ao engendrar um Ocidente que é somente seu - ao menos, de mais nenhuma outra Arte -, consegue radicalmente inventar: a do indivíduo diviso, todo e parte hegelianos, opostos heraclitianos, polêmicos.

Muito embora o colonialismo dos séculos XVI-XVII tenha produzido uma riquíssima Iiteratura de viagens, somente no século XIX é que ele efetivamente consegue propiciar as condições de nascimento da Etnologia. Aqui o espanto cede posição à rotina, que procura transformar a diferença na degenerescência ou no progresso. Não afirmo agora que a Etnologia é "filha do colonialismo" decimonônico - aí suposta uma relação "colaboracionista" - ou, por outro lado, especulo sobre se a situação colonizadora (Foucault 1985) é indispensável ou não à disciplina. Embora não descarte a relevância destas duas direções de indagação, minhas intenções ora me levam para sentidos bem diferentes de inquirição da problemática 35 .

Nos limiares do presente século e flagrantemente sob condições propiciadas pelos correspondentes sistemas de relações das nações-estados modernos europeus entre si e com suas colônias, dá-se o cruzamento da Etnologia com a Música. Isto vem a subsidiar uma modalidade nova de imaginação da interconjunção "nós "/" outros". Tal novidade se evidencia pela intersecção da tematização etnológica do "homem" (Foucault 1985: 36 1-403) com uma correspondente da música, histórico-musicai. Observe-se que a relação "nós"/"outros" é congênita à invenção da Música Ocidental, o que eu creio já ter suficientemente elaborado.

O que se dá aqui, agora, porém, no cenário internacional-colonial em epígrafe não havia ainda aparecido sob o sol: partituras crítico-interpretativas que etnografam a música do passado - e, logo, gravações fonográficas que asilam o exacústico do "outro". A novidade, entretanto, não se esgota aí: na visão de seus próprios nativos, a Música Ocidental começa então a viver crises que cada vez mais lhe ameaçam as bases recônditas, diligentemente trabalhadas por séculos - romantismo extremado, nacionalismos e dissolução da tonalidade. A Música Ocidental, assim, periga de não ser mais o kathólon da ocidentalidade européia, esta, por outro lado - e consistentemente -, em graves crises também. Note-se que esta sensação de morte da Música Ocidental - da Grande Música de Adorno -, tão bem teorizada por Leibowitz, é contemporânea de um acelerado

35 Sobreas relações estre Antropologia e colonialismo, em termos do funcionalismo britânico, vide os opostos Leclerc (197 3) e Kuper (1978: 121-145). Para um debate mais amplo, sobre a conjunção Antropologia-imperialismo, vide Monod et alii (1 970-7t) e Clastres et alii (1971). 
incremento de seu consumo fonográfico, de uma "popularização" que a outrifica como, ela mesma e toda ela, música do passado.

O primeiro encontro etno-musico-Iógico se dá em fins do século XIX, expressando-se pela ereção da Escola de Berlim de Musicologia Comparada. Em função do terror nazista, este encontro foi dissolvido na Europa, tendo de emigrar para os Estados Unidos na década de 30. Aqui, ele hiberna durante duas décadas, restabelecendo-se maduro nos anos 50 como a disciplina Etnomusicologia. O que a Música foi buscar com esses encontros foi legitimidade científica, ilustração e exemplo tendo sido a demanda primeiro da Psicologia, depois da Antropologia junto ao território musicai. Na base do segundo encontro, está um crescente mercado de "música exótica", bem como a consolidação - a partir dos anos 50 - de uma poderosa indústria cultural (ou cultura de massa) de música popular. Esta música, em tomo do eixo jazz-rock, invade o planeta como novo kathólon. Ela, usando cada vez mais elementos e processos das "músicas exóticas" - ao tempo em que mantendo, enquanto sistema tonal e universo de valores, uma impressionante continuidade com a Música Ocidental - passa a ser empregada como um dos idiomas mais cruciais do "compromisso político", especificamente das lutas étnicas. Este novo kathólon não mais aponta, como o da Música Ocidental, para um Ocidente tópico, europeu, mas para uma ocidentalidade planetária.

Aí estará, em suma, o nexo fundamental do encontro etno-musico- lógico: na invenção da Música Ocidental como música do passado e na entronização da música popular como novo universal. Esta, a sua mercabilidade, não tanto enquanto aos dinheiros aí envolvidos - que são feitiços - mas muito mais no pertinente às relações sociais das quais as pecúnias, moedas e dinheiros são sím-bolos - no caso, um bazar de identidades, de "cabeças feitas", cosmetizadas pela música.

\section{Agradecimentos}

Este texto é uma revisão, quase apenas redacional, do primeiro capítulo de minha dissertação de doutorado (Menezes Bastos, 1990). Aos membros da banca de defesa (Profs. Dominique Gallois, Eduardo Viveiros de Castro, José Miguel Wisnik e Roberto Cardoso de Oliveira), meus agradecimentos pelas contribuições. A Profa. Lux B. Vidal, minha orientadora, a gratidão pela generosidade. Esta revisão foi feita entre 1992-94, quando eu era Visiting Scholar no Anthropology Program do Massachusetts Institute of Technology. Agradeço à Profa. Jean Jackson, chefe do Programa, ao Prof. James Howe, membro do mesmo, a Priscilla Cobb, seu coordenador, e a Kathleen Spinale, sua secretária, pelo apoio durante minha estadia no MIT. Ainda do MIT, agradeço a ajuda do Prof. David Epstein, do Departamento de Música. No Brasil, sou grato à CAPES pela bolsa de pós-doutorado (Proc. 2403/92-7). As Profas. IIka Boaventura Leite, Miriam Pillar Grossi, Jean Langdon, Dennis Werner, Silvio Coelho dos Santos, Elsje Maria Lagrou e Alberto Groisman, colegas da Área de 
Antropologia do Departamento de Ciências Sociais da Universidade Federal de Santa Catarina, devo gentilezas impagáveis durante todo esse período. Os Profs. Anthony Seeger, Gerard Béhague, Dieter Christensen, Roberto Dalvlatta, Terence Turner, Greg Urban, Steven Feld, John Shepherd, David MayburyLewise Michael Herzfeld foram extremamente atenciosos nessa minha passagem pela América do Norte. Agradeço aos Profs. Julio Cezar Melatti e José Jorge de Carvalho, da equipe do Anuário Antropológico, pelas sugestões no sentido da presente revisão, sendo eu, porém, o único e exclusivo responsável por ela. Darlinda Moreira, Agenor Farias, Giselle Ferreira, Ralph Waddey e José Pedro Fonseca ajudaram-me, com amizade e carinho, na introdução à vida no estrangeiro. 


\section{Referências Bibliográficas}

ADLER, Guida. 1885. "Umfang, Method und Ziel der Musikwi ssen schaft". Vierteljahresschrifrfür Musikwissenschaft I: 5-20.

ADORNO, Theodor. 1974. Filosofia da Nova Música. São Paulo: Perspectiva.

1983a. "Idéias Para a Sociologia da Música". ln Benjamin, Habermas, Horkheimer, Adorno (P. E. Arantes, org.). São Paulo: Abril Cultural. pp. 259-268.

. 1983b. "O fetichismo na Música e a Regressão da Audição". In Benjamin, Habermas, Horkheimer, Adorno (P. E. Arantes, org.). São Paulo: Abril Cultural. pp. 165-191.

. 1986; "A Indústria Cultural". ln Sociologia: T. W. Adorno (G.

Cohn, org.). São Paulo: Atica. pp. 92-99.

AGOSTINHO, Santo. 1987. "Confissões (397-401)". ln Santo Agostinho (J. A. M. Pessanha, org.). São Paulo: Abril. pp. 9-288.

ALBERSHE M, G. On the Psychology of Music, in lnternationat Review o1the Aesthetics and Sociology 01 Music, 4(2): 2 13-221 (1973).

ARANTES, P. E. 1983. "Vida e Obra". In Benjamin, Habermas, Horkheimer, Adorno (P.E. Arantes, org.). São Paulo: Abril. pp. vii-xix.

BAKER, T. 1882. Über die Musik der Nordam erikanisch e Wilden. Leipzig.

BARTÓK, Béla. 1981. Escritos sobre a Música Popular. Méxic o: Siglo Veintiuno.

BEATO, Cláudio C. (s.d.). Músicos Brasileiros: "Eruditos" e "Populares", Tese de Mestrado em Sociologia, IUPERJ.

BECKER, Howard S. 1970. Sociological Work: Method and Substance. New Brunswick: Transaction Books.

BÉHAGUE, G. 1975. "From the Editor". Ethnomusicology 19 (2): iv.

. 1986. O Impacto Mundial da Música e das Instituições Musicais Portuguesas: Um Esboço Preliminar. Comunicação apresentada ao Colóquio Internacional Portugal e o Mundo - Processos Interculturais na Música: O Papel de Portugal na Música do Mundo desde o Século XV (Lisboa, dezembro de 1986) [colóquio organizado pelo International Council for Traditional Music e pela Universidade Nova de Lisboa]. 
BENJAMIN, Walter. 1983. "A Obra de Arte na Época de suas Técnicas de Reprodução". In Benjamin, Habermas, Horkheimer, Adorno (P. E. Arames, org.). São Paulo: Abril. pp .3-28.

BLACKING, J. 1977. L'Homme Producteur de Musique (seconde partie). Musique en leu 29:108-116.

Washington Press. 1983. How Musical is Man? Seattle and London: University of

BLAUKOPF, Kurt. 1951. Musiksoziologie. Eine Einfiihrung in die Grundbegrieffe mit Besonder Berücksichtigun $g$ der Soziologie der Tonsysteme. Wien.

BOAS, Franz. 1955. Primitive Art. New York: Dover. . 1988. The Central Eskimo. Toronto: Coles.

BOEHMER, Konrad. 1972. Adorno, Musique, Societé. Musiqu e en leu 7: 34-43.

BOILES, Charles \& 1. J. NATTIEZ. 1977. Petite Histoire Critique de I'Ethnomusicologie. Musique en leu 28 : 26-53.

BOSE, F. 1972. Die Musik der Tukáno und Desána. Jahrbu ch fuer Musikatisches Volks unâ Voelkerkunde 6.

BOULEZ, Pierre. 1972. A Música Hoje. São Paulo: Perspectiva.

BOURDIEU, Pierre. 1983. "O Campo Científico". In Bourdieu (Renato Ortiz, org.). São Paulo: Ática. pp. 122-155.

BRUM, Marciano. 11\97. Atravez da Música: Bosquejos Históricos. Rio de Janeiro: Officinas Gráphicas de I. Bevilacqua \& C.

CARDOSO DE OLIVEIRA, Roberto. 1976. "Processos de Articulação Étnica". In Identidade, Etnia e Estrutura Social (Roberto Cardoso de Oliveira). São Paulo: Pioneira. pp . 53-78.

CARPEAUX, Otto M. 1959. História da Literatura Ocidental. Rio de Janeiro: O Cruzeiro. (8 volumes).

. 1977. Uma Nova História da Música. 3a. edição. Rio de Janeiro:

Alhambra.

CHARLES, Daniel et alii. 1972. Relire Adorno. Musique en l eu 7.

CHASE, Gilbert. 1958. The Music o1 Spain. New York: Dover.

. 1976. "Musicology, History, and Anthropology: Currents Thoughts". In Current Thought in Musicology (J.W. Grubbs, ed.). Auslin: University of Texas Press. pp. 231246. 
CLASTRES, Pierre et alii. 1971. Anthropologie er Impérialisme (II). Les Temps Modernes 299/300 : 2345-2407.

COHN, Gabriel 1986. "Introdução: Adorno e a Teoria Critica da Sociedade". In T. W. Adorno. (Gabriel Cohn, org.). São Paulo: Ática. pp. 7-30.

COPANS, Jean. 1974. "Da Etnologia à Antropologia". ln Antropologia ; Ciência das Sociedades Primitivas? (J. Copans et aliiv. Lisboa: Edições 70. pp . 13-56.

COROMINAS, J. 1954. Dicionarin Crítico Etimológico de la Lengua Castellana, Madrid:Editorial Gredos (4 volumes).

CORREA DE AZEVEDO, Luís Heitor. 1952. Bibliografia Musical Brasileira (1820-1950). Rio de Janeiro: Instituto Nacional do Livro.

DAHLBACK, K. 1958. New Methods in Vocal Folk Music Research. Oslo: Oslo University Press.

DENSMORE, Frances. 1922. Northern Ute Music, Washington : Smithsonian Institutional Bureau of American Ethnology (Bulletin 75).

DUMONT, L. 1970. Homo Hierarchicus: Ensayo sobre el Sistema de Castas. Madrid: Aguilar.

1985. O Individualismo: Uma Perspectiva Antropológica da Ideologia Modema. Rio de Janeiro: Rocco.

ENGELMANN, Amo. 1978. "Introdução". ln Wolfgang Kõhler (Amo Engelmann, org.). São Paulo: Atica. pp. 7-36.

ETZKORN, K. Peter. 1973. "Sociologists and Music". In Music and Society: The Later Writings of Paul Honigsheim (Peter K. Etzkorn, ed.). New York: John Wiley \& Sons. pp. 3-40.

396. . 1985. Letter from the Editor. Ethnomusicology 29 (3 ): 395 -

ETZKORN, K. Peter, ed. 1973. Music and Society: The Later Writings of Paul Honigsheim. New York: John Wiley \& Sons.

FELD, Steven. 1982. Sound and Sentiment: Birds, weeping, Poetics and Song in Kaluli Expression, Philadelphia: University of Pennsylvania Press.

Yearbook for Traditional Music 16: 1- 18.

- 1984. Communication, Music, and Speech about Music. Resenha de How Musical is Man?, de J. Blacking. Manuscrito citado em Boilês e Nattiez 1977.

FOUCAULT, Michel. 1985. As Palavras e as Coisas: Uma Arqueologia das Ciências Humanas. São Paulo: Martins Fontes. 
FREIDSON, Eliot (org.). 1971, The Professions and Their Prospects. Beverly Hills: Sage Publications.

GEERTZ, C. 1978. A Interpretação das Culturas. Rio de Janeiro: Zahar.

GELAIT, R. 1977. The Fabulous Phonograph, 1877-19 77. New York: Macmillan.

GILLIS, Frank L. 1980. Alan P. Merriam (1923- 1980). Ethnomusicology 24 (3): v-vi.

GILMAN, B. I. 1891. Zuni Melodies. Journal of American Ethnology and Archaeology I.

GOODE, W. 1969. "The Theoretical Limits of Professionalization". In The SemiProfessions and their Organization: Teachers, Nurses, Social Workers (Arnitai Etzioni, org.). New York: Collier Macmillan.

GRAF, Walter. 1974. Die Vergleichende Musikwissen schafl in Õsterreich seit 1896. Yearbook for Traditional Music 6: 15-43.

GRAMSCI, Antonio. 1968. Os Intelectuais e a Organização da Cultura. Rio de Janeiro: Civilização Brasileira.

HALLOWELL, A. I. 1976. "The Beginnings of Anthropology in America ". In Selected Papers from the American Anthropologist (1888-1920) (F. de Laguna, ed.). Washington: American Anthropological Association. pp. 1-90.

HAMELINE, Jean -Yves. 1978. "Histoire de la Musique et de ses Effects". ln Le Pouvoir des Sons (E. Durnaurier, org.). Paris: Institut National de I'Audiovisuel. pp. 11-35.

HARRIS, Marvin. 1979. EI Desarollo de la Teoria Antropológica: Una História de las Teorias de la Cultura. México: Siglo Veintiuno.

HARRISON, F. L. 1963. "American Musicology and the European Tradition". In Musicology (F. L. Harrison et alii). Westport: Greenwood Press. pp. 1-85.

HEGEL, G. W. F. 1974. Estética: Pintura e Música (Livro VI da Estética). Lisboa: Guimarães.

HEIDBREDER, Edna. 1964. Psicologias del Siglo XX. Buenos Aires: Paidos.

HEIDEGGER, Martin. 1984. "A Coisa". In Mitologia (Eudoro de Sousa, tradutor). Lisboa: Guimarães. pp. 235-271.

HERSKOVITS, Melville J. 1944. Drums and Drummers in Afro-Brazilian Cult Life. Musical Quarterly 30: 479-492.

HERZOG, G. 1935. Special Song Types in North American Indian Music. Zeitschrift für Yergleich ende Musikwis sens chaft 3 (112): 1 -11. 
. 1949. "Salish Music", In Indians of the Urban Northwest (M.W.

Smith, ed.). New York: Columbia University Press. pp. 93-109.

HINDLEY, Geoffrey (ed.). 1977. The Larousse Encyclopaedia of Music, London: Hamlyn.

HOOD, Mantle. 1960. The Challenge of "Bi-Musicality". Ethnomusicology 4 (2): 55-59.

HORNBOSTEL, Erich M. von. 1982. "La Música de los Makuschi, Taulipang y Yekuana. Ln DeI Roraima ai Orinoco (1'. Koch-Grünberg). Caracas: Banco Central de Venezuela, $3^{\circ}$ volume, pp. 331 -366.

IMBERTY, Michel. 1979. Entendre la Musique: Sémantique Psychologique de la Musique. Paris: Bordas.

1981. Les Écritures du Temps: Sémantique Psychologique de la

Musique. Tome 2. Paris: Bordas.

JACOB, L. (ed.). 1845. Oeuvres de F. Rabelais. Paris: Charpentier Librairie - Éd ileur.

JAEGER, Werner. 1965. Cristianismo Primitivo y Paidéia Griega. México: Fondo de Cultura.

KANT, Immanuel. 1961. Critica del Juicio. Buenos Aires: Losada.

KOCH-GRÜNBERG, T. 1982. Del Roraima al Orinoco. Caracas: Banco Central de Venezuela. (3 volumes).

KOLINSIG. M. 1936. "Suriname Music". In Suriname Folklore. (M.J. Herskovits \& Frances S. Herskovns, eds.). New York. pp. 489 -758 (Columbia University Contributions to Anthropology 27).

Musicales I: 191-215.

1949. La Música dei Oeste Africano. Revista de Estúdios . 1959. The Evaluation of Tempo. Ethnomusicology 3: 45 -57.

KUHN. T.S. 1975. A Estrutura das Revoluções Cientificas. São Paulo: Perspectiva.

KUNST. J. 1950. Musicologica: A Study of the Nature of Ethno-Musicology, its Problems, Methods and Representative Personalities. Amsterdam Koninklijke Vereeging Indisch Insrirur.

KUPER. A. 1978. Antropólogos e Antropologia. Rio de Janeiro: F. Alves.

LANGER, Susanne K. 1960. Philosophy in a New Key. Cambridge: Harvard University Press. 
LARSON, M. Sarfary, 1977. The Rise of Professionalism, A Sociological Analysis, Berkeley: University of Califomia Press.

LECLERC, G. 1973. Crítica da Antropologia. Lisboa: Estampa.

LEIBOWITZ, René. 1957. La Evolución de la Música: de Bach a Sch6nberg. Buenos Aires: Nueva Visión.

LEUCHTER, Erwin. 1946. La História de la Música como Reflejo de la Evolución Cultural. Buenos Aires: Ricordi.

LÉVI-STRAUSS, C. 1962. A Crise Moderna da Antropologia. Revista de Antropologia 10 (12): 19-26.

. 1969. "O Futuro dos Estudos de Parentesco". ln Organização Social (Roque de Barros Laraia, org.). Rio de Janeiro: Zahar. pp. 124-150.

.1970. "Introdução: História e Etnologia". ln Antropologia Estrutural (C. Lévi-Strauss). Rio de Janeiro : Tempo Brasileiro. pp. 15-43.

LOMAX, A. 1968. Folk Song Style and Culture. Washington: American Association for the Advancement of Science.

LUCAS, Maria Elizabeth. 1980. "Classe Dominante e Cultura Musical no Rio Grande do Sul: Do Amadorismo à Profissionalização". ln Rio Grande do Sul: Cultura e Ideologia (l. H. Dacanal, org.). Porto Alegre: Mercado Aberto. pp. $150-167$.

LYONS, John. 1974a. Introduction to Theoreticat Linguistics. Cambridge University Press. . 1974b. Semântica Estrutural. Lisboa: Presença.

MANNHEIM, Karl. 1950. Ideologia e Utopia . Porto Alegre: Globo.

MAUSS, Marcel. 1979. "A Prece" [1909]. In Antropologia: Marcel Mauss (R. Cardoso de Oliveira, org.). São Paulo: Ática. pp. 102-146.

MCALLESTER. David P. 1954. Enemy Way Music. Peabody Museum Papers 41 (3).

Ethnomusicology 7 (3) : 182-186.

MCLEOD, Norma. 1973. From the Editor. Ethnomusicology 17 (2): v-vi.

MENEZES BASTOS, Fernando José de. 1987. Panorama das Idéias Estéticas no Ocidente (de Platão a Kant). Brasília: Editora Universidade de Brasília. 
. 1973. Categorias de Canais sensoriais perceptuais e de Campos Percepto-Cognitivos: Um Ensaio sobre a Codificação Sensorio-Perceptual da Cognição Brasileira. Manuscrito.

. 1977. "Situación del Músico en la Sociedad" ln América Latina en su Música (I. Arelz, relatora). México: Siglo Veintiuno. pp. 103-138.

.1982. Musique et Societé au resu: Introduction au Language Musical Brésilien. Cultures 8 (2): 54-73.

. 1983. Elementos para uma Reflexão Inicial Sobre a Questão da Preparação para o Trabalho: Conceituação e Valoração de "Trabalho". Manuscrito.

1986a. "Mas eu não entendo nada de música". Para uma Crítica Antropológica a Etnomusicologia ou ao Casamento da Antropologia Sem Música com a Musicologia Sem Homem. Comunicação apresentada à $15^{\mathrm{a}}$ Reunião Brasileira de Antropologia (Curitiba, março de 1986), GT "Antropologia Estética e Ergologia (Lux VidaI e Berta Ribeiro, coordenadores).

- 1986b. Ser indio, Cantando Música Portuguêsa: Manipulação Etnica e musical entre os Indios Kiriri de Mirandela, Estado da Bahia, Brasil. Comunicação apresentada ao Colóquio Internacional Portugal e o Mundo Processos Interculturais na Música e Papel de Portugal na Música do Mundo desde o Século $X V$ (Lisboa: dezembro [colóquio organizado pelo International Council for Traditional MUSIC e pela Universidade Nova de Lisboa).

- 1990. A Festa da Jaguatirica - Uma Partitura CriticoInterpretativa, Tese de Doutorado em Antropologia Social, Universidade de São Paulo.

. 1993. Between Authenticity and Entertainment: Towards a Anthropological History of Ethnic Folkways Library. Research Project presented to Smithsonian Institution.

MERRIAM, Alan P. 1951. Songs of the Afro-Bahian Cults: an Ethnomusicological Analysis, Tese de doutorado em Antropologia, Northwestern University.

1964. The Anthropology of Music. Northwestern University

Press.

1967. Ethnomusicology of the Flathead Indians, New York:

Werner-Green.

. 1969. Ethnomusicology Revisited. Ethnomusicology 13 (2): 213-

229.

1977. Definitions of Comparative "musicology" and "Ethnomusicology": A Historical-Theoretical Perspective. Ethnomusicology 21 (2): 189-204. 
MERRIAM, Alan P. et alii. 1966. The Anthropology of Music - a CA Book REVIEW. Current Anthropology 7 (2): 2 17-2 30.

MEYER, Leonard B. 1967. Music, The Arts and Ideas. Chicago: University of Chicago Press.

MOLAND Louis (ed.), 1950. Oeuvres de Rabelais. Tome II. Paris: Editeurs Garnier Frêres.

MONOD, Jean et alli. 1970-1971. Anthropologie et Impérialisme. Les Temps Modernes 293 /294: 1061-1201.

NATTIEZ, J .L. 1975. Fondements d'une Sémiologie de la Musique. Paris: Union Générale d 'Édileurs.

NETTL. Bruno. 1956. Music in Primitive Culture. Cambridge: Harvard University Press.

Press. . 1964. Theory and Method in Ethnomusicology, London: Free

PESSANHA, José Américo Morta. 1979. "Platão: Vida e Obra" (José Américo Motta Pessanha, org.). São Paulo: Abril. pp. v-xxiv.

PINTO, Tiago de Oliveira. 1983. Considerações sobre a Musicologia Comparada Alemã Experiências e Implicações no Brasil. Boletim da Sociedade Brasileira de Musicologia 1: 69-106.

RANDEL, Don Michael (ed.). 1978. The Harvard Concise Diccionary of Music. Cambridge: The Belknap Press of Harvard University Press.

READ, O. \& Walter L. WELCH. 1976. From Tin Foil to Stereo: Evolution of the Phonograph. 2nd. ed. Indian apoías: Howard W. Sons \& Co., Inc. and the Bobbs-Merrill Coo.

REDFIELD, Robert et alii. 1936. Memorandum on the Study of Acculturation, American Anthropologist 38: 148-152.

RICE, T. 1983. From the Editor. Ethnomusicology 27 (2): v.

RIEMANN, H. 1908. Grundiss der Musikwissenschaft, WissetlSchaft und Bildung 34 .

RITZER, G. 1971. "Prófessionalism and the Individual". In The Professions and Their Prospects (E. Freidson, org.). Beverly Hills: Sage Publications. pp. 59 -75.

ROBERTS, Helen H. 1933. Form in Primitive Music. New York: Norton. . Musical Areas of Aboriginal North American Indians, New Haven: Yale University Press (Publication in Anthropology 12). 
ROUSSEAU, J .J. 1978. "Ensaio sobre a Origem das Línguas no qual se fala da Melodia e da Imitação Musical". ln Rousseau (M.S. Chauí, org.). São Paulo: Abril. pp. 159 -199.

ROWELL, Lewis. 1987. Introducción a la Filosofia de là Música: Antecedentes Históricos e Problemas Estéticos. Barcelona: Gedisa.

SACHS, Curto 1947. História Universal de los Instrumentos Musicales. Buenos Aires: Cenrurion. 1953. Rhythm and Tempo. New York: Norton. 1962. The Welsstring of Music. The Bague: M. Nijhoff.

SCHNEIDER, Marius. 1952. Contribuición a la Música Indígena de Mato Grosso (Brasil). Anuário Musical 7: 159-175.

SEEGER, Charles. 1956. History of Past Organizations to the Founding of SEM. EthnoMusicology Newsletter 6: 1-3.

Califomia Press. 1977. Studies in Musicology: 1935-1975. Berkeley: University of

SHEPHERD, John et alii. 1977. Whose Music? A Sociology of Musical Languages, London: Transaction Books.

SOUSA, Eudoro (ed.). 1966. A Poética de Aristóteles. Porto Alegre: Globo.

SPENGLER, Oswald. 1973. A Decadência do Ocidente: Esboço de uma Morfologia da História Universal. 23 edição condensada. Rio de Janeiro: Zahar.

STONE, Ruth M. \& Nancy A. CASSEL. 1986. From the Editors. SEM Newsletter 20 (3): 2.

STUMPF, Carl. 1883. Tonpsychologie. Vol. I. Leipzig. 1886. Lieder der Bellakul a Indianer. Vierteljahresschrift fiir Musikwissenschaft 2: 405426. . 1890. Tonpsychologie. Vol. II. Leipzig.

SUPICÍC, Ivo. 1971. Musique et Societé: Perspectives pour une Sociologie de la Musique. Zagreb: Institut de Musicologie.

TELLO, Francisco José León. 1962. Estudios de História de la Teoria Musical. Madrid: Instituto Español de Musicologia.

TINHORÃO, José Ramos. 1981. Música Popular: do Gramofone ao Rádio e TV. São Paulo: Atica. 
TOFFANIN, Giuseppe. 1965. Storia Letteraria d'ltalia, II Cinquecento. 73 ed. Milano: Casa Editrice Dr. Francesco Vallardi.

TOYNBEE, A. 1963. Estudio de la História. Vol. XII: Las Perspectivas de la Civilización Occidental, Buenos Aires: Ernecé.

TRAJANO FILHO, Wilson. 1984. Músicos e Música no Meio da Travessia. Dissertação de Mestrado, Universidade de Brasília.

WARD, John Owen (ed.). 1975. The Concise Oxford Dictionary of Music. London: Oxford University Press.

WARMINGTON, Erich H. \& Philip G. ROUSE (eds.). 1956. "Platos The Republic", ln Great Dialogues of Plato (E .H. Warmington \& P.G. Rouse, eds.). New York: The New American Library. pp. 125-422.

WATERMAN, Richard A. 1952. "African Influence on the Music of the Américas". Ln Acculturation in the Americas (Sol Tax, ed.). Proceedings of the 29th International Congress of Americanists. Vol. II: 207-218.

WEBER, Max. 1944. "Los Fundamentos Racionales y Sociológicos de la Música". In Economia y Sociedad (Max Weber). México: Fondo de Cultura. vol. II, pp. 1118-1183.

WEBERN, Anton. 1984. O Caminho para a Música Nova. São Paulo: Novas Melas.

WILENSKY, Harold L. 1970. "The Professionalizarion of Everyone?" $\ln$ The Sociology of Organizations: Basic Studies (O. Grusky \& G. A. Miller, eds.). New York: The Free Press. pp. 483-501. 